\title{
Impact of snow deposition on major and trace element concentrations and elementary fluxes in surface waters of the Western Siberian Lowland across a $1700 \mathrm{~km}$ latitudinal gradient
}

\author{
Vladimir P. Shevchenko ${ }^{1}$, Oleg S. Pokrovsky ${ }^{2}$, Sergey N. Vorobyev ${ }^{3}$, Ivan V. Krickov ${ }^{3}$, Rinat M. Manasypov ${ }^{3,4}$, \\ Nadezhda V. Politova ${ }^{1}$, Sergey G. Kopysov ${ }^{3}$, Olga M. Dara ${ }^{1}$, Yves Auda ${ }^{2}$, Liudmila S. Shirokova ${ }^{2,4}$, Larisa \\ G. Kolesnichenko ${ }^{3}$, Valery A. Zemtsov ${ }^{3}$, and Sergey N. Kirpotin ${ }^{3}$ \\ ${ }^{1}$ Shirshov Institute of Oceanology RAS, 36 Nakhimovsky Pr., Moscow, Russia \\ ${ }^{2}$ Geosciences Environment Toulouse, UMR 5563 CNRS, University of Toulouse, \\ 14 Avenue Edouard Belin 31400, Toulouse, France \\ ${ }^{3}$ BIO-GEO-CLIM Laboratory, Tomsk State University, 36 Lenina, Tomsk, Russia \\ ${ }^{4}$ N. Laverov Federal Center for Integrated Arctic Research, IEPS, \\ Russian Academy of Science, Arkhangelsk, Russia
}

Correspondence to: Oleg S. Pokrovsky (oleg.pokrovsky@get.omp.eu)

Received: 7 November 2016 - Discussion started: 22 November 2016

Revised: 12 September 2017 - Accepted: 15 October 2017 - Published: 17 November 2017

\begin{abstract}
In order to better understand the chemical composition of snow and its impact on surface water hydrochemistry in the poorly studied Western Siberia Lowland (WSL), the surface layer of snow was sampled in February 2014 across a $1700 \mathrm{~km}$ latitudinal gradient (ca. 56.5 to $\left.68^{\circ} \mathrm{N}\right)$. We aimed at assessing the latitudinal effect on both dissolved and particulate forms of elements in snow and quantifying the impact of atmospheric input to element storage and export fluxes in inland waters of the WSL. The concentration of dissolved+colloidal $(<0.45 \mu \mathrm{m}) \mathrm{Fe}, \mathrm{Co}, \mathrm{Cu}, \mathrm{As}$ and $\mathrm{La}$ increased by a factor of 2 to 5 north of $63^{\circ} \mathrm{N}$ compared to southern regions. The $\mathrm{pH}$ and dissolved $\mathrm{Ca}, \mathrm{Mg}, \mathrm{Sr}, \mathrm{Mo}$ and $\mathrm{U}$ in snow water increased with the rise in concentrations of particulate fraction (PF). Principal component analyses of major and trace element concentrations in both dissolved and particulate fractions revealed two factors not linked to the latitude. A hierarchical cluster analysis yielded several groups of elements that originated from alumino-silicate mineral matrix, carbonate minerals and marine aerosols or belonging to volatile atmospheric heavy metals, labile elements from weatherable minerals and nutrients. The main sources of mineral components in PF are desert and semi-desert regions of central Asia.
\end{abstract}

The snow water concentrations of DIC, $\mathrm{Cl}, \mathrm{SO}_{4}, \mathrm{Mg}$, $\mathrm{Ca}, \mathrm{Cr}, \mathrm{Co}, \mathrm{Ni}, \mathrm{Cu}, \mathrm{Mo}, \mathrm{Cd}, \mathrm{Sb}, \mathrm{Cs}, \mathrm{W}, \mathrm{Pb}$ and $\mathrm{U}$ exceeded or were comparable with springtime concentrations in thermokarst lakes of the permafrost-affected WSL zone. The springtime river fluxes of $\mathrm{DIC}, \mathrm{Cl}, \mathrm{SO}_{4}, \mathrm{Na}, \mathrm{Mg}, \mathrm{Ca}$, $\mathrm{Rb}, \mathrm{Cs}$, metals ( $\mathrm{Cr}, \mathrm{Co}, \mathrm{Ni}, \mathrm{Cu}, \mathrm{Zn}, \mathrm{Cd}, \mathrm{Pb}$ ), metalloids (As, $\mathrm{Sb})$, Mo and $\mathrm{U}$ in the discontinuous to continuous permafrost zone $\left(64-68^{\circ} \mathrm{N}\right)$ can be explained solely by melting of accumulated snow. The impact of snow deposition on riverine fluxes of elements strongly increased northward, in discontinuous and continuous permafrost zones of frozen peat bogs. This was consistent with the decrease in the impact of rock lithology on river chemical composition in the permafrost zone of the WSL, relative to the permafrost-free regions. Therefore, the present study demonstrates significant and previously underestimated atmospheric input of many major and trace elements to their riverine fluxes during spring floods. A broader impact of this result is that current estimations of river water fluxes response to climate warming in high latitudes may be unwarranted without detailed analysis of winter precipitation. 


\section{Introduction}

The snow cover exhibits a number of properties making it a unique natural archive and indicator of the ecosystem status (Baltrènaite et al., 2014; Bokhorst et al., 2016; Callaghan et al., 2011; de Caritat et al., 1998, 2005; Garbarino et al., 2002; Guéguen et al., 2016; Kashulina et al., 2014; Lisitzin, 2002; Niu et al., 2016; Ross and Granat, 1986; Singh et al., 2011; Siudek et al., 2015; Van de Velde et al., 1999; Walker et al., 2003). The snow washes out insoluble aerosol particles from the atmosphere as well as soluble compounds, including various pollutants (Telmer et al., 2004; Barrie, 1986; Tranter et al., 1986, 1987). Unlike rain, the snow remains at the soil surface and thus records all atmospheric input during the glacial period of the year. In boreal and subarctic regions, both dissolved and particulate fractions of snow water reflect the air chemistry in winter, when the land is covered by snow and the water surfaces are frozen. During winter, the input of mineral compounds from adjacent regions is minimal and the main factor controlling chemical composition of snow is long-range, over hundreds and thousands of kilometers, atmospheric transport (Franzén et al., 1994; Huang et al., 2015; Shevchenko, 2003, Shevchenko et al., 2000, 2010, 2016; Welch et al., 1991; Zdanowicz et al., 1998, 2006; Krachler et al., 2005; Zhang et al., 2015).

Several studies of major elements and some trace metals in particulate fraction of snow have been conducted in western Siberia (Boyarkina et al., 1993; Ermolov et al., 2014; Kashulina et al., 2014; Moskovchenko and Babushkin, 2012; Shevchenko et al., 2015; Talovskaya et al., 2014). The dissolved $(<0.45 \mu \mathrm{m}$ or $<0.22 \mu \mathrm{m})$ fraction of snow was traditionally studied in European subarctic (de Caritat et al., 1998; Chekushin et al., 1998; Kashulina et al., 2014; Reimann et al., 1991, 2000; Reinosdotter and Viklander, 2005) but the data on trace elements in snow water collected in boreal, Arctic and subarctic regions are limited. This is especially true for large and geographically homogeneous territories of western Siberia, presenting relatively similar levels of snow deposition during winter seasons (i.e., from $100 \mathrm{~mm}$ of water in the south to $140-150 \mathrm{~mm}$ of water in the north) without any pronounced influence of large industrial centers, mountain regions and marine aerosols over the territory close to 1.5 million $\mathrm{km}^{2}$ (Resources of Surface Waters of USSR, 1972, 1973; Boyarkina et al., 1993).

The originality of the present study consists of (i) sampling of substantial $(\sim 1700 \mathrm{~km})$ latitudinal transect in relatively pristine zones comprising forest, forest tundra and tundra within the permafrost-free, discontinuous and continuous permafrost regions, and (ii) assessment of both dissolved + colloidal and particulate forms of major and trace elements in snow samples. Given the scarcity of available measurements of snow chemical and particulate composition in western Siberia, we aimed at addressing the following specific issues: (1) characterizing the effect of the latitude on major and trace element concentration in dissolved $(<0.45 \mu \mathrm{m})$ and particulate ( $>0.45 \mu \mathrm{m}$ ) fractions of snow; (2) testing the link between dissolved and particulate fractions of elements and the impact of particle mineralogy on snow chemical composition; (3) comparing dissolved concentrations of major and trace elements in snow to those in lakes and rivers across the latitudinal gradient of the WSL; and (4) assessing the share of snow deposition on seasonal and annual export of dissolved elements by western Siberian rivers. Via addressing quantitatively the abovementioned issues using an identical methodology over a large territory $\left(56\right.$ to $\left.68^{\circ} \mathrm{N}\right)$ of orographically flat low-population-density terrain, we anticipate to enhance our knowledge of the winter atmospheric deposition in western Siberia, in the absence of direct influence of marine aerosols and large industrial centers. This should eventually allow evaluation of the impact of snow deposition on chemical composition and elementary fluxes of subarctic inland waters across a large latitudinal gradient of climate and permafrost parameters.

\section{Study site, materials and methods}

\subsection{Geographic settings}

The Western Siberia Lowland, located between the Ural mountains and the Yenisei River, extends over $2000 \mathrm{~km}$ from south to north and presents highly homogeneous, from a physico-geographical point of view, taiga, forest-tundra and tundra landscapes comprising bogs and mires in the permafrost-free zone and thermokarst lakes developed on flat peat bogs (palsa) in the permafrost-bearing zone. Detailed physico-geographical description, hydrology, lithology and soils can be found in earlier works (Botch et al., 1995; Smith et al., 2004; Frey and Smith, 2007; Beilman et al., 2009) and in our recent geochemical studies (Manasypov et al., 2014; Stepanova et al., 2015; Pokrovsky et al., 2015; Raudina et al., 2017). Because of its flat orographic context, extensive vegetation cover and relative remoteness from the Arctic coast (except the north of the Gyda and the Yamal peninsulas), the atmospheric precipitates in winter are likely to bear the signature of remote desert and semi-desert regions of Central Asia. The anthropogenic impact is not expected to be strongly pronounced because of (i) low population density (average 6 people $\mathrm{km}^{-2}$ but only $0.5-2$ people $\mathrm{km}^{-2}$ in the northern half of the WSL) and (ii) moderate local pollution from the gas burning in oil wells mostly in the permafrostfree zone, south of the town of Surgut. The part of the WSL north of $64^{\circ} \mathrm{N}$ contains essentially gas exploration facilities (no gas burning) and minimally impacts the environment. Taken together, the latitudinal profile of the WSL presents a unique opportunity to study the chemistry of atmospheric deposits within a highly homogeneous physico-geographical context and relatively low local anthropogenic impact. 


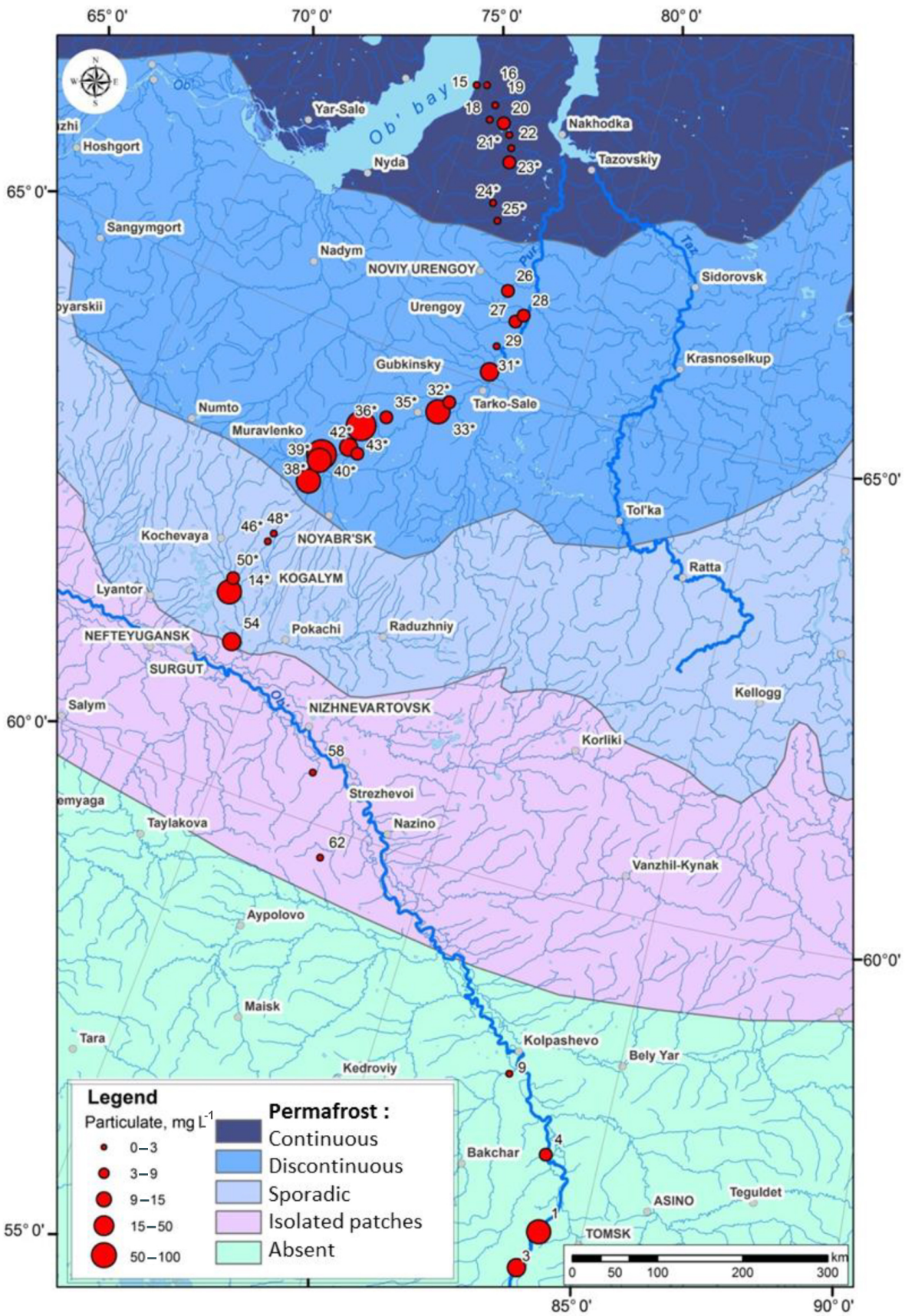

Figure 1. Map of the study site with permafrost zone boundaries. The size of the sampling points reflects the concentration of particulate fraction ( $\mathrm{mg} \mathrm{L}_{\text {snow water }}^{-1}$. The boundaries of permafrost zones are from Brown et al. (1997).

\subsection{Snow sampling}

The snow of the WSL was sampled along the latitudinal transect $\mathrm{S} \rightarrow \mathrm{N}$, from the vicinity of the city of Tomsk (zone of southern taiga) to the eastern coast of the Ob estuary (tundra zone) from 19 February 2014 to 5 March 2014 (Fig. 1). The possible sources of snow deposition and the pathways of aerosols transport to the WSL were reconstructed by analyzing meteorological maps and by calculating back trajecto- ries of air transport to the observation points using NOAA's HYSPLIT model (Draxler and Rolf, 2003). In order to assess a snapshot of snow deposition across a $1700 \mathrm{~km}$ latitudinal profile and collect the freshest snow that was subject to minimal transformation, we chose to sample only the upper layer of the snow cover. This technique, in contrast to traditional sampling of entire snow columns (i.e., Guéguen et al., 2016; Niu et al., 2017), allows an adequate representation of 
the upper fresh snow layer that had minimal transformation at the soil, and frequently used in remote regions (Kang et al., 2007; Zhang et al., 2015). The isotope composition of collected snow proved its fresh character, not subject to any metamorphism (Vasil'chuk et al., 2016).

The upper $0-5 \mathrm{~cm}$ of snow was sampled in 39 locations (Fig. 1). All sampling points were located more than $500 \mathrm{~m}$ from the winter road. The sampling was performed using a metal-free technique, in a protected environment, using precleaned plastic shovel and vinyl single-use gloves. Approximately $30 \mathrm{~L}$ of snow was collected into single-use polyethylene bags. These polyethylene bags were thoroughly washed with $1 \mathrm{M} \mathrm{HCl}$ and abundant Milli-Q water in the clean room class A 10000 . In the laboratory, the snow was melted at ambient temperature, and filtered through pre-weighted acetate cellulose filters (Millipore, $47 \mathrm{~mm}$ diameter) of $0.45 \mu \mathrm{m}$ pore size. The storage of unfiltered snow water samples was less than $1 \mathrm{~h}$ at $4{ }^{\circ} \mathrm{C}$.

\subsection{Particle analyses}

The sizes and morphology of particles on filters and elemental composition of individual particles were studied using a VEGA 3 scanning electron microscope (SEM) (Tescan) with an INCA Energy microprobe attachment (Oxford Instruments). The mineralogical composition of particulate fraction on selected filters was studied by X-ray powder diffractometric method on a D8 ADVANCE (Bruker AXS) $X$-ray diffractometer equipped with a LYNXEYE linear detector (Lisitzin et al., 2015). The uncertainty of the relative proportion of mineral composition was $1-2 \%$ and the detection limit was $1 \%$.

Freshly melted snow water was filtered through preweighted $0.45 \mu \mathrm{m}$ acetate cellulose (Millipore) filters. These filters were placed in Petri dishes, dried at $60^{\circ} \mathrm{C}$ in an oven and digested using microwave acid attack, which comprised $6.5 \mathrm{~mL}$ concentrated $\mathrm{HNO}_{3}, 3.5 \mathrm{~mL}$ concentrated $\mathrm{HCl}$ and $0.5 \mathrm{~mL}$ concentrated $\mathrm{HF}$. $\mathrm{HNO}_{3}$ and $\mathrm{HCl}$ were bi-distilled in the clean room and HF was of commercial ultra-pure quality (Fluka). The filters were reacted $30 \mathrm{~min}$ in ultrasonic bath prior full digestion using a Mars 5 microwave digestion system (CEM, France). For this, 10 samples of filters, 1 certified 2711a Montana II Soil standard and 1 blank filter sample were loaded into Teflon reactors subject to treating at $150^{\circ} \mathrm{C}$ during $20 \mathrm{~min}$. After completing the digestion, the content of reactors was transferred to $30 \mathrm{~mL}$ Savilex vials and evaporated at $70^{\circ} \mathrm{C}$. The residue was dissolved in $10 \mathrm{~mL}$ of $10 \%$ $\mathrm{HNO}_{3}$ and dilutes by $2 \% \mathrm{HNO}_{3}$ prior to the analyses. For the analysis of snow particles on filters, the blanks were estimated after digestion of six random filters. In the digestion solution, the concentrations of all trace elements were a factor of 10 to 100 lower than that obtained from the filters with particles after $0.5-1.0 \mathrm{~L}$ of snow water filtration. The concentration of major and trace elements (TEs) in filter digestion products was measured using an ICP-MS Ag- ilent 7500ce with $\sim 3 \mu \mathrm{g} \mathrm{L}^{-1}$ of indium and rhenium as internal standards. Four in-house external standards were analyzed every 10 samples. Necessary corrections for oxide and hydroxide ion interferences were made for rare earth elements (REEs) and metals (Ariés et al., 2000). Based on replicate analyses of in-house standards and certified materials, the uncertainty for TE measurement ranged from $5 \%$ at $0.1-100 \mu \mathrm{g} \mathrm{L}^{-1}$ to $10 \%$ at $0.001-0.01 \mu \mathrm{g} \mathrm{L}^{-1}$. Analyses of low concentrations of $\mathrm{Hf}, \mathrm{Ge}, \mathrm{Cs}, \mathrm{Ga}$, and $\mathrm{W}$ (e.g., on the order of $0.001 \mu \mathrm{g} \mathrm{L}{ }^{-1}$, comparable with detection limits) was possible with a minimal estimated uncertainty of $20 \%$.

\subsection{Melted snow analyses}

The $\mathrm{pH}$ and specific conductivity were measured on unfiltered snow water samples using Hanna portable instruments. The dissolved $(<0.45 \mu \mathrm{m})$ fraction of snow water was obtained via filtration using a polycarbonate Nalgene vacuum filter unit, and a PVC-made Mityvac hand vacuum pump. This fraction included colloidal and truly dissolved (ionic) forms. Blanks of Milli-Q water were also placed in polyethylene bags for the same time as melting snow $\left(\leq 1 \mathrm{~h}\right.$ at $\left.4{ }^{\circ} \mathrm{C}\right)$ and processed via filtration similar to snow samples. The filtrates were divided into two parts: one was acidified with double distilled $\mathrm{HNO}_{3}$ acid and stored in pre-cleaned HDPE vials for ICP MS analysis, while the second part was stored in HDPE bottles without acidification, for dissolved organic and inorganic carbon analysis (DOC and DIC, respectively), and anion analysis.

The major anion concentrations $\left(\mathrm{Cl}^{-}, \mathrm{SO}_{4}^{2-}\right)$ in the $<0.45 \mu \mathrm{m}$ fraction were measured using ion chromatography (HPLC, Dionex ICS 2000i), with an uncertainty of $2 \%$, estimated from the replicate analyses of PERADE and RAIN international certified materials. The DOC and DIC in this fraction were analyzed using a carbon total analyzer (Shimadzu TOC-VSCN) with an uncertainty of $5 \%$ and a detection limit of 0.1 and $0.05 \mathrm{mg} \mathrm{L}^{-1}$, respectively.

Filtered snow water samples were analyzed with an Element XR ICP MS, allowing for much better precision of the analyses of highly diluted samples and avoiding many interferences compared to Agilent 7500ce. The uncertainty of the Element XR analysis was $\pm 5 \%$, while its detection limit was a factor of 100 lower than the traditional (Agilent) instrument. The Element XR operated in three modes depending on the elements measured: low resolution for $\mathrm{B}, \mathrm{Rb}, \mathrm{Sr}, \mathrm{Zr}$, Mo, Cd, Sb, Cs, Ba, REEs, Hf, W, Pb, Th and U; medium resolution for $\mathrm{Na}, \mathrm{Mg}, \mathrm{Al}, \mathrm{Si}, \mathrm{P}, \mathrm{Ca}, \mathrm{Ti}, \mathrm{V}, \mathrm{Cr}, \mathrm{Mn}, \mathrm{Fe}, \mathrm{Co}$, $\mathrm{Ni}, \mathrm{Cu}, \mathrm{Zn}, \mathrm{Ga}$ and $\mathrm{Sr}$; and high resolution for $\mathrm{K}$ and As. The agreement between two instruments for most elements was within $10 \%$. The international geostandards SLRS-5 (Riverine Water References Material for Trace Metals certified by the National Research Council of Canada) was used to assess the validity and reproducibility of the analyses. For all major and most trace elements in the snow water, the concentrations in the blanks were below or comparable with analytical de- 
tection limits $\left(\leq 0.1 \mathrm{ng} \mathrm{L}^{-1}\right.$ for $\mathrm{Cd}, \mathrm{Ba}, \mathrm{Y}, \mathrm{Zr}$, REEs, $\mathrm{Hf}, \mathrm{Pb}$, Th and $\mathrm{U} ; 1 \mathrm{ng} \mathrm{L}{ }^{-1}$ for $\mathrm{Ga}, \mathrm{Ge}, \mathrm{Rb}, \mathrm{Sr}$ and $\mathrm{Sb} ; \sim 10 \mathrm{ng} \mathrm{L}^{-1}$ for $\mathrm{Ti}, \mathrm{V}, \mathrm{Cr}, \mathrm{Mn}, \mathrm{Fe}, \mathrm{Co}, \mathrm{Ni}, \mathrm{Cu}, \mathrm{Zn}$ and $\mathrm{As}$ ). These values were at least 5 times lower than the average concentration of trace elements in snow samples. Most TEs presented in this work exhibited $\leq 15 \%$ agreement between the certified or recommended values and our measurements. The TEs for which certified or recommended data were not available were considered only for the cases where we obtained good analytical reproducibility (i.e., the relative standard deviation based on our standard measurements was $\leq 10 \%$ ).

\subsection{River fluxes and snow storage}

The mass balance calculation of the degree of snowmelt influence on element fluxes in WSL rivers was performed, taking into account (i) the water stock in snow (in millimeters of snow water accumulated during winter), fairly well known for western Siberia (Karnatzevitch and Khruschev, 2014; Resources of Surface Waters of USSR, 1972, 1973; Zakharova et al., 2011), and (ii) the springtime river runoff (in millimeters during May and June) calculated from hydrological parameters. For water stock calculation, we used the available mean multi-annual daily and monthly discharges of WSL rivers across the latitudinal profile (Resources of Surface Waters of USSR, 1972 and 1973 and recently complied in the database R-AcricNET (http://www.r-arcticnet.sr.unh. edu). The WSL territory is covered by Russian Hydrological Survey (RHS) gauging stations which allowed calculation of the discharge during May-June as described elsewhere (Pokrovsky et al., 2015). The most recent complete hydrological data of small- and medium-sized rivers in permafrostaffected area of the WSL (Novikov et al., 2009) were used together with the RHS database to calculate the spring flood fluxes of individual rivers and snow water stock for three latitudinal zones: $56-60,60-64$ and $64-68^{\circ} \mathrm{N}$. Note that a comparison between the elementary snow stock and the river elementary discharge could not be performed for individual river watersheds, since no snow water chemical data are available with the necessary spatial resolution. Therefore, we compared the winter snow stock with riverine spring flood fluxes of major and trace elements for three latitudinal zones. For this, both spring flood flux of individual rivers and snow water stock were averaged for each latitudinal zone.

\subsection{Statistical methods}

Statistical analysis of the average, median and geometric mean values and the link between element concentrations in suspended and dissolved fractions as well as comparison of different sampling sets (snow water and snow particles) included ANOVA, the $\mathrm{H}$ criterion of the Kruskal-Wallis and Mann-Whitney U tests. These tests allowed evaluating the difference between two sets of data separately for each TE following the approaches developed for lakes and rivers of western Siberia (Manasypov et al., 2014, 2015; Pokrovsky et al., 2015, 2016a). The multiple regressions were performed for quantifying the relationship between dissolved and particulate concentration of TE and the latitudinal trends of concentrations and enrichment factors. More thorough statistical treatment of both log-transformed and non-transformed major and TE concentration in dissolved and particulate fraction of snow samples in each location included a normed principal component analysis (PCA) using the ADE-4 R package (Thioulouse et al., 1997; Chessel et al., 2004) using the methods for scores and variables (De la Cruz and Holmes, 2011).

To identify the group of elements that behaved in a similar way in snow water and snow particles, we applied a complementary hierarchical cluster analysis (HCA; Hartigan, 1975; Kaufman and Rousseeuw, 2005), which is widely adopted in geochemical interpretations of element concentration data (e.g., Bini et al., 2011; Levitan et al., 2015; Schot and van der Wal, 1992; Moragues-Quiroga et al., 2017). We used Ward's method (Ward, 1963) for the linkages rule, following previous studies (Gourdol et al., 2013; Lin et al., 2014). The Pearson correlation distance was used for the linkage distance, which is frequently used for cluster variables (Reimann et al., 2008). These choices are in agreement with the group search of the PCA loadings.

In order to assess the degree of element fractionation in snow particles, the Al-normalized TE enrichment factor (EF) with respect to the average upper part of continental Earth crust (Rudnick and Gao, 2003) was calculated according to

$\mathrm{EF}=\frac{[\mathrm{TE}] /[\mathrm{Al}]_{\text {sample }}}{[\mathrm{TE}] /[\mathrm{Al}]_{\text {crust }}}$.

For the assessment of the element enrichment factor in snow particles, a normalization to both general upper Earth crust and the local geological background (soil, peat and moss) was used. The reason for this is that, unlike in studies of the local pollution tracing in the European Arctic (e.g., within the Kola Ecogeochemistry project; see de Caritat et al., 1997; Reimann and de Caritat, 2000; Reimann et al., 2000) or small-scale stream bed sediments or soils (MoraguesQuiroga et al., 2017; Levitan et al., 2015) where the normalization to the local soil or bedrock was necessary, the present study essentially deals with winter-period long-range atmospheric transport of soluble and mineral forms of elements. As such, following the common practice in this field, the normalization to upper Earth crust allowed assessing the true enrichment/depletion of the atmospheric aerosols. However, in order to better represent the elementary features of snow particles, the concentration of elements in PF was also compared with western Siberian mineral soils, peat and moss. 


\section{Results}

\subsection{Soluble fraction of the snow water}

The latitude-averaged concentrations of dissolved and particulate fraction of snow samples are listed in Table 1. A full data set of major and TE concentrations in snow water is given in the "Data availability" section. Examples of the effect of latitude on dissolved $(<0.45 \mu \mathrm{m})$ element concentrations are shown in Fig. 2. Fe and $\mathrm{Cu}$ exhibited a 2- to 5fold increase in dissolved concentrations north of $63^{\circ} \mathrm{N}$ (at $p<0.05)$. $\mathrm{Zn}$ and $\mathrm{Pb}$ did not exhibit any systematic effect of latitude, and $\mathrm{Sb}, \mathrm{Cd}$ and $\mathrm{Ni}$ exhibited a single maximum at ca. $63-65^{\circ} \mathrm{N}$. For As we identified two maxima, at 63.5 and $67.5^{\circ} \mathrm{N}$ with an overall 2- to 3-fold decreasing trend northward. All other major and trace elements did not reveal systematic variations in concentrations as a function of latitude (not shown).

The PCA treatment of soluble fraction suggested that at least two factors are interpretable. The PC1 $\times$ PC2 correlation circle revealed two large groups of variables (Fig. 3a). The first group is composed of $\mathrm{Al}, \mathrm{Fe}, \mathrm{Cr}, \mathrm{Zr}, \mathrm{Pb}$ and REEs corresponding to lithogenic, poorly soluble trace elements. The second large group is composed of DOC, $\mathrm{K}, \mathrm{Rb}, \mathrm{Cs}, \mathrm{Mn}$, $\mathrm{Co}, \mathrm{Ba}, \mathrm{Sb}, \mathrm{Co}, \mathrm{Mo}, \mathrm{Mg}, \mathrm{Si}, \mathrm{Sr}, \mathrm{Na}, \mathrm{Ca}$ and pH. These highly mobile elements presumably reflect the marine aerosols and leaching from soluble soil minerals such as carbonates as well as plant biomass. Similar factors determine chemical composition of snow water regardless of the latitude of the sampling, and no specific conditions or limiting factors depended on geographical location.

The HCA was conducted on the basis of the first two factors of the PCA. The criterion of non-intersection between the groups allowed partitioning the chemical elements of the dissolved part into six specific groups presented in Fig. 3b. These groups characterize the elements according to their general chemical properties, ability to mobilize in aqueous solution from the solid minerals, affinity to the biota or their presence in the contaminated particles of industrial activity. Thus, the first two groups of the dissolved fraction shown in Fig. $3 b$ and encircled in Fig. 3a comprise low-mobility elements that likely originated from the alumino-silicate mineral matrix (Al, $\mathrm{Cr}$, REEs, $\mathrm{Ti}, \mathrm{Zr}, \mathrm{Fe}, \mathrm{V})$ as well as some volatile heavy metals typically present in the solid aerosol particles $(\mathrm{Cu}, \mathrm{Cd}, \mathrm{Pb})$. The fourth group includes major constituents of carbonate or marine aerosols matrix (elevated $\mathrm{pH}$, $\mathrm{Mg}, \mathrm{Ca}$ and $\mathrm{Na}$ ). The fifth group is represented by typical macro- and micronutrients ( $\mathrm{K}, \mathrm{Rb}, \mathrm{Mn}, \mathrm{Co}, \mathrm{Ba})$. Finally, the last (sixth) group of elements comprises both labile elements linked to weatherable minerals $(\mathrm{Sr}, \mathrm{Sb}, \mathrm{Si}, \mathrm{Ni}$ ) and nutrients such as $\mathrm{Sr}, \mathrm{Ni}, \mathrm{Si}, \mathrm{DOC}$ and Mo. Three of these elements are strongly enriched in snow particles relative to the Earth crust ( $\mathrm{Sr}, \mathrm{Sb}$, Mo; see Sect. 3.3 below), thus suggesting their possible leaching from atmospheric dust into the soluble fraction of snow. We could not find a straightforward explication of the common group of $\mathrm{Zn}$ and $\mathrm{U}$ in soluble snow fraction (Fig. 3b)

The effect of particulate fraction on dissolved element composition in snow is illustrated in Fig. 4, where the values of $\mathrm{pH}$ (Fig. 4a), Sr (Fig. 4b), $\mathrm{Al}$ (Fig. 4c) and Pb (Fig. 4d) in the dissolved fraction are plotted as a function of total particle concentration in snow water. The elements of the fourth and fifth group ( $\mathrm{Ca}, \mathrm{Mg}, \mathrm{Sr}, \mathrm{Mn}$, and $\mathrm{Co}$ ) increase their concentration in snow water by ca. an order of magnitude with the increase in particle concentration by 2 orders of magnitude. The insoluble hydrolysates ( $\mathrm{Fe}, \mathrm{Al}$, light REEs, $\mathrm{Zr}$ ), $\mathrm{Cu}$ and $\mathrm{Pb}$ belonging to first and second HCA group decrease their concentration (less than a factor of 10) when the particle concentration increases by 2 orders of magnitude. Other elements in the $<0.45 \mu \mathrm{m}$ fraction exhibit the variations within an order of magnitude (DOC, DIC, $\mathrm{Na}, \mathrm{Cl}, \mathrm{SO}_{4}, \mathrm{~K}, \mathrm{Si}, \mathrm{Cr}$, V, $\mathrm{Ni}, \mathrm{Cu}, \mathrm{Zn}, \mathrm{As}, \mathrm{Sb}, \mathrm{Rb}, \mathrm{Cd}, \mathrm{Cs}, \mathrm{Ba}$, heavy REEs and $\mathrm{U}$ ) or 2 orders of magnitude (Ti, Ga, Mo, W) and do not exhibit any significant (at $p<0.05)$ link with particle concentration.

\subsection{Particle concentration and TEs in the particulate fraction of snow}

Concentration of particulate fraction (PF) of snow and its elementary composition are available in the "Data availability" section. The mineralogical composition of most representative snow samples is given in Table S1 of the Supplement. The dominant minerals are quartz (37\%), albite $(13 \%)$, Kfeldspar $(13 \%)$, phlogopite $(10 \%)$, chrysotile $(8 \%)$, illite $(7 \%)$, and chlorite $(5 \%)$. The concentration of dolomite and calcite ranges from 1 to 48 and 1 to $19 \%$, respectively. Although mineral components dominated the composition of the particulate fraction, the PF also contained organic fibers, diatom frustules, pollens and particles produced during fuel burning (fly ash and black carbon). The concentration of particles in snow water ranged from 0.4 to $67 \mathrm{mg} \mathrm{L}^{-1}$. The highest values are encountered in the vicinity of Tomsk (No SF 1) and around the towns of Surgut (no. SF 54, 14), Nojabrsk (SF 36, SF 38) and Gubkinsky (SF 33). Although the proportion of fly ash and black carbon in these samples is significant and higher than in the rest of samples as deduced from SEM observation, the mineral particles $(1-25 \mu \mathrm{m}$ size) still dominate. Note that the high content of fly ash and fuel burning spheres was not linked $(p>0.05)$ to high particulate and dissolved elements. The lowest concentrations of particles $\left(<5-10 \mathrm{mg} \mathrm{L}^{-1}\right)$ were recorded north of $65^{\circ} \mathrm{N}$, the region of gas industry, and between 58 and $61^{\circ} \mathrm{N}$, corresponding to the winter road along the Ob River with very low population density.

The enrichment coefficient ranged from $\sim 1-5$ (Ga, REEs, $\mathrm{Fe}$ ) to $>100$ (Mo, W, As, Sb, Ni, Cu, Pb, Mg, Ca, Na) as illustrated in Fig. 5a. The highest enrichment $(\mathrm{EF} \geq 1000)$ is observed of $\mathrm{Sb}, \mathrm{Zn}$ and $\mathrm{Cd}$. The variation in the enrichment factor as a function of latitude is shown for elements most enriched in particulate fraction in Fig. S1 of the Supplement. 
Table 1. Minimal, maximal, median and geometric mean concentration of dissolved $\left(\mu \mathrm{g} \mathrm{L}_{\text {snow water }}^{-1}\right), n=35$, and particulate $\left(\mu \mathrm{g} \mathrm{g}_{\text {particles }}^{-1}\right)$, $n=34$ snow components. The data for upper continental crust (UPC) are from Rudnick and Gao (2003). N.A. stands for not analyzed.

\begin{tabular}{|c|c|c|c|c|c|c|c|c|c|}
\hline \multirow[b]{2}{*}{ Element } & \multicolumn{4}{|c|}{ Dissolved } & \multicolumn{4}{|c|}{ Particulate } & \multirow[t]{2}{*}{ UPC } \\
\hline & Min & Max & Median & $\begin{array}{r}\text { Geometric } \\
\text { mean }\end{array}$ & Min & Max & Median & $\begin{array}{r}\text { Geometric } \\
\text { mean }\end{array}$ & \\
\hline $\mathrm{pH}$ & 4.38 & 8.73 & 5.11 & 5.44 & N.A. & N.A. & N.A. & N.A. & N.A. \\
\hline $\mathrm{SC}, \mu \mathrm{S} \mathrm{cm}^{-1}$ & 9 & 35 & 15.5 & 16.3 & N.A. & N.A. & N.A. & N.A. & N.A. \\
\hline $\mathrm{DIC}, \mathrm{mg} \mathrm{L}^{-1}$ & 0.26 & 2.12 & 0.37 & 0.47 & N.A. & N.A. & N.A. & N.A. & N.A. \\
\hline $\mathrm{DOC}, \mathrm{mg} \mathrm{L}^{-1}$ & 0.46 & 1.87 & 0.84 & 0.85 & N.A. & N.A. & N.A. & N.A. & N.A. \\
\hline $\mathrm{Cl}, \mathrm{mg} \mathrm{L}^{-1}$ & 0.07 & 2.94 & 0.51 & 0.48 & N.A. & N.A. & N.A. & N.A. & N.A. \\
\hline $\mathrm{SO}_{4}, \mathrm{mg} \mathrm{L}^{-1}$ & 0.41 & 2.01 & 0.71 & 0.72 & N.A. & N.A. & N.A. & N.A. & N.A. \\
\hline $\mathrm{Li}$ & N.A. & N.A. & N.A. & N.A. & 2.6 & 32.2 & 10.8 & 10.7 & 24 \\
\hline $\mathrm{Be}$ & N.A. & N.A. & N.A. & N.A. & 0.12 & 2.11 & 0.59 & 0.59 & 2.1 \\
\hline $\mathrm{Na}$ & 47 & 1982 & 295 & 303 & 1452 & 39156 & 6717 & 7314 & 24200 \\
\hline $\mathrm{Mg}$ & 19 & 862 & 114 & 114 & 3492 & 156712 & 19089 & 21411 & 14900 \\
\hline $\mathrm{Al}$ & 1.6 & 35.2 & 15.5 & 12.3 & 6444 & 138267 & 31079 & 31565 & 81500 \\
\hline $\mathrm{P}$ & N.A. & N.A. & N.A. & N.A. & 70 & 1928 & 481 & 503 & 660 \\
\hline $\mathrm{Si}$ & 3.5 & 180 & 64.6 & 33.2 & N.A. & N.A. & N.A. & N.A. & N.A. \\
\hline K & 39.2 & 120 & 55.5 & 63.0 & 1682 & 38395 & 5895 & 6023 & 23200 \\
\hline $\mathrm{Ca}$ & 57 & 2266 & 267 & 296 & 3944 & 159272 & 17331 & 17775 & 25600 \\
\hline $\mathrm{Ti}$ & 0.001 & 0.338 & 0.032 & 0.018 & 194 & 5762 & 674 & 689 & 3800 \\
\hline $\mathrm{V}$ & 0.007 & 0.221 & 0.051 & 0.049 & 23.8 & 322 & 67.4 & 69.7 & 97 \\
\hline $\mathrm{Cr}$ & 0.027 & 0.340 & 0.111 & 0.117 & 43.8 & 841 & 138 & 156 & 92 \\
\hline $\mathrm{Mn}$ & 0.62 & 9.54 & 3.06 & 2.99 & 180 & 1242 & 400 & 404 & 780 \\
\hline $\mathrm{Fe}$ & 1.8 & 62.2 & 14.6 & 12.0 & 7206 & 41255 & 15873 & 16488 & 39100 \\
\hline $\mathrm{Co}$ & 0.006 & 0.418 & 0.097 & 0.094 & 5.9 & 60.7 & 19.4 & 18.6 & 17.3 \\
\hline $\mathrm{Ni}$ & 0.04 & 5.66 & 0.36 & 0.36 & 28.1 & 1067 & 149 & 145 & 47 \\
\hline $\mathrm{Cu}$ & 0.16 & 2.51 & 0.57 & 0.63 & 13.1 & 273 & 63.4 & 75.1 & 28 \\
\hline $\mathrm{Zn}$ & 1.7 & 31.0 & 8.3 & 8.3 & 70.7 & 3832 & 202 & 255 & 67 \\
\hline $\mathrm{Ga}$ & 0.0001 & 0.0185 & 0.0023 & 0.0014 & 1.8 & 26.7 & 8.32 & 7.73 & 17.5 \\
\hline $\mathrm{Ge}$ & N.A. & N.A. & N.A. & N.A. & 0.36 & 3.18 & 0.88 & 0.91 & 1.4 \\
\hline As & 0.02 & 0.46 & 0.19 & 0.15 & 3.8 & 67.2 & 16.1 & 16.0 & 4.8 \\
\hline $\mathrm{Rb}$ & 0.033 & 0.262 & 0.066 & 0.075 & 6.1 & 124 & 24.1 & 23.4 & 84 \\
\hline $\mathrm{Sr}$ & 0.26 & 10.2 & 1.04 & 1.23 & 26.2 & 580 & 117 & 115 & 320 \\
\hline $\mathrm{Y}$ & N.A. & N.A. & N.A. & N.A. & 1.52 & 40.2 & 7.1 & 7.5 & 21 \\
\hline $\mathrm{Zr}$ & 0.0001 & 0.0403 & 0.0024 & 0.0015 & 7.7 & 383 & 36.8 & 38.5 & 193 \\
\hline $\mathrm{Nb}$ & N.A. & N.A. & N.A. & N.A. & 0.80 & 25.5 & 3.54 & 3.72 & 12 \\
\hline Mo & 0.0001 & 0.059 & 0.010 & 0.005 & 0.55 & 10.4 & 2.12 & 2.24 & 1.1 \\
\hline $\mathrm{Cd}$ & 0.015 & 0.180 & 0.047 & 0.046 & 0.11 & 3.37 & 0.71 & 0.71 & 0.09 \\
\hline $\mathrm{Sn}$ & N.A. & N.A. & N.A. & N.A. & 1.13 & 29.3 & 7.76 & 7.36 & 2.1 \\
\hline $\mathrm{Sb}$ & 0.009 & 0.132 & 0.036 & 0.038 & 1.67 & 27.2 & 5.96 & 6.15 & 0.4 \\
\hline Cs & 0.0015 & 0.0105 & 0.0034 & 0.0036 & 0.32 & 4.78 & 1.35 & 1.24 & 4.9 \\
\hline $\mathrm{Ba}$ & 0.74 & 13.6 & 3.35 & 3.32 & 88 & 1664 & 374 & 391 & 628 \\
\hline $\mathrm{La}$ & 0.001 & 0.049 & 0.012 & 0.011 & 2.0 & 60.2 & 10.3 & 10.8 & 31 \\
\hline $\mathrm{Ce}$ & 0.003 & 0.095 & 0.022 & 0.019 & 4.05 & 128 & 19.0 & 20.6 & 63 \\
\hline $\operatorname{Pr}$ & 0.0001 & 0.0084 & 0.0022 & 0.0019 & 0.50 & 15.5 & 2.30 & 2.35 & 7.1 \\
\hline $\mathrm{Nd}$ & 0.0013 & 0.0275 & 0.0085 & 0.0067 & 1.86 & 58.6 & 8.32 & 8.70 & 27 \\
\hline $\mathrm{Sm}$ & 0.0001 & 0.0072 & 0.0020 & 0.0016 & 0.39 & 11.8 & 1.78 & 1.79 & 4.7 \\
\hline $\mathrm{Eu}$ & 0.00010 & 0.00253 & 0.00096 & 0.00083 & 0.11 & 2.56 & 0.45 & 0.47 & 1.0 \\
\hline Gd & 0.0004 & 0.0082 & 0.0022 & 0.0022 & 0.40 & 10.3 & 1.71 & 1.77 & 4.0 \\
\hline Dy & 0.00002 & 0.0041 & 0.0016 & 0.0008 & 0.32 & 7.83 & 1.35 & 1.42 & 3.9 \\
\hline Ho & 0.00006 & 0.00123 & 0.00061 & 0.00054 & 0.06 & 1.51 & 0.26 & 0.27 & 0.83 \\
\hline $\mathrm{Er}$ & 0.0002 & 0.0029 & 0.0010 & 0.0010 & 0.18 & 4.71 & 0.77 & 0.80 & 2.3 \\
\hline $\mathrm{Tm}$ & 0.00002 & 0.00088 & 0.00011 & 0.00009 & 0.03 & 0.72 & 0.11 & 0.11 & 0.3 \\
\hline $\mathrm{Yb}$ & 0.00000 & 0.00289 & 0.00089 & 0.00049 & 0.16 & 4.91 & 0.73 & 0.73 & 1.96 \\
\hline $\mathrm{Lu}$ & N.A. & N.A. & N.A. & N.A. & 0.024 & 0.76 & 0.11 & 0.11 & 0.31 \\
\hline $\mathrm{Hf}$ & N.A. & N.A. & N.A. & N.A. & 0.25 & 13.2 & 1.10 & 1.18 & 5.3 \\
\hline
\end{tabular}


Table 1. Continued.

\begin{tabular}{lrrrr|rrrrr}
\hline & \multicolumn{4}{c|}{ Dissolved } & \multicolumn{3}{c}{ Particulate } & UPC \\
\cline { 2 - 7 } Element & Min & Max & Median & $\begin{array}{r}\text { Geometric } \\
\text { mean }\end{array}$ & Min & Max & Median & $\begin{array}{r}\text { Geometric } \\
\text { mean }\end{array}$ \\
\hline $\mathrm{Ta}$ & N.A. & N.A. & N.A. & N.A. & 0.18 & 4.35 & 0.62 & 0.62 & 0.9 \\
$\mathrm{~W}$ & 0.002 & 0.108 & 0.020 & 0.017 & 2.0 & 102 & 35.9 & 28.8 & 1.9 \\
$\mathrm{Tl}$ & N.A. & N.A. & N.A. & N.A. & 0.04 & 0.73 & 0.23 & 0.23 & 0.90 \\
$\mathrm{~Pb}$ & 0.02 & 3.67 & 0.51 & 0.38 & 13.2 & 703 & 71.9 & 67.9 & 17 \\
$\mathrm{Th}$ & N.A. & N.A. & N.A. & N.A. & 0.43 & 17.1 & 2.22 & 2.33 & 10.5 \\
$\mathrm{U}$ & 0.0007 & 0.0063 & 0.0031 & 0.0028 & 0.19 & 4.69 & 0.92 & 0.93 & 2.7 \\
\hline
\end{tabular}

For $\mathrm{Mg}, \mathrm{Ca}, \mathrm{Sr}, \mathrm{Ba}, \mathrm{Fe}, \mathrm{Mn}, \mathrm{Co}, \mathrm{Ni}, \mathrm{K}, \mathrm{Rb}, \mathrm{Cs}, \mathrm{V}, \mathrm{Cr}, \mathrm{As}$, $\mathrm{Cd}$ and $\mathrm{W}$ the EF exhibits a maximum around $63-64.5^{\circ} \mathrm{N}$. This maximum coincides with the maximum of particulate fraction concentration (not shown).

The majority of chemical elements are present in particulate rather than dissolved form in snow meltwater samples. This is illustrated by a histogram of the ratios averaged over the complete latitudinal profile (Fig. 5b). Although the variations in this ratio for different snow water samples across the WSL achieve \pm 0.5 order of magnitude, the average values shown in this figure illustrate the importance of particulate deposition of Al, Fe, Ga, REEs, Cr, V, Ti, Zr, Mo and W. For other elements, particulate and dissolved inputs in the form of snow are within the same order of magnitude. Some soluble elements such as $\mathrm{Na}, \mathrm{Cd}, \mathrm{Ca}, \mathrm{Sr}, \mathrm{Ba}, \mathrm{K}$, As and Zn exhibit the dominance of dissolved transport in snow.

Although the use of average crust for assessment of element enrichment in snow particles is justified by long-range transfer of snow components, it has been known since the works of the Reimann and de Caritat groups in NW Europe that the "average crust" is unlikely to represent the local background and the use of the "upper crust" average value can introduce a 2 to 3 orders of magnitude uncertainty to any calculated EF (de Caritat et al., 1997; Reimann and de Caritat, 2000; Reimann et al., 2000). As such, western Siberia moss, peat and clay/loam horizons were used to assess relative enrichment of elements in snow particles. It can be assumed that the leaching of soluble forms of elements from these solid phases in winter is highly unlikely. The specificity of western Siberia is that the mineral ("geological") local substrate is completely frozen, even in summer, since the active (unfrozen) layer depth does not exceed the peat thickness, and in that case, the use of "organic" substrates is most relevant. All three WSL reference substances ("local" moss, peat and clays) represent latitudinally averaged values based on large $(>50)$ number of samples collected in previous studies across the $1700 \mathrm{~km}$ latitudinal gradient.

The elementary ratios of snow particles to that in mineral soil, peat and moss of the WSL are illustrated in Fig. 6a, $\mathrm{b}$, and $\mathrm{c}$, respectively. Given significant variation on the latitude-averaged values of element concentration in snow particles, mineral, peat and moss of soil column, the deviation of the ratios from unity is significant if it exceeds a factor of 2 to 3 . Compared to mineral soil of the WSL, the snow particles are strongly $(\geq 10 \times)$ enriched in $\mathrm{Sb}, \mathrm{Zn}, \mathrm{Ni}$ and $\mathrm{Cd}$ and to a lesser degree $(\geq 5 \times)$ in $\mathrm{Mg}, \mathrm{Ca}, \mathrm{Pb}, \mathrm{Mo}$, and As (Fig. 6a). Note that western Siberian soils, developed on sand and clay (silt) deposits (Vasil'evskaya et al., 1986), are quite poor in $\mathrm{Ca}$ and $\mathrm{Mg}$, especially in the permafrost-bearing zone north of $62^{\circ} \mathrm{N}$. The enrichment of snow particles relative to peat is observed for all elements, being particularly high $(>50 \times)$ for $\mathrm{Ni}, \mathrm{Cr}, \mathrm{Pb}, \mathrm{Cu}, \mathrm{Zn}, \mathrm{Mg}, \mathrm{Na}$ and $\mathrm{Sb}$ (Fig. 6b). Only $\mathrm{P}, \mathrm{Ge}$ and $\mathrm{Cd}$, exhibiting high affinity to peat (Shotyk et al., 1990, 1992), are not significantly $(p>0.05)$ higher in snow particles compared to the peat column. Finally, the mosses are most depleted in all elements relative to snow PF, with only biogenic elements (P, K, Rb, Mn and $\mathrm{Cd}$ ) known to be concentrated in bryophytes being non-significantly higher in snow particles relative to mosses (Fig. 6c).

The PCA of the elementary composition of the particulate fraction demonstrated the F1 $\times$ F2 structure (Fig. S2a of the Supplement). Here, two groups can be distinguished: highly mobile elements ( $\mathrm{Na}, \mathrm{Ca}, \mathrm{V}, \mathrm{Ni}, \mathrm{Mg}, \mathrm{Mn}$ ) and lowmobility elements (REEs, $\mathrm{Zr}, \mathrm{Pb}, \mathrm{Cd}, \mathrm{Ga}, \mathrm{P}$ ). Note here that $\mathrm{Pb}$ is present as low-mobility ferric colloids in organic and Fe-rich surface waters of the WSL (Pokrovsky et al., 2016b) but it is considered as volatile in the atmospheric transport, especially in the case of fuel burning (Reimann et al., 2000). For the particulate fraction, the HCA attributed the elements to five formal groups shown in Fig. S2b and encircled in Fig. S2a. This distinction, however, is less certain than that of the dissolved fraction and does not allow establishing a clear link between the selected groups and physico-chemical properties of elements or their possible sources in the snow particles. Thus, in the first group, among three labile elements ( $\mathrm{Mg}, \mathrm{Na}$ and $\mathrm{Ca}$ ) we identified $\mathrm{V}$, which may exhibit elevated mobility in the form of anion in carbonate-bearing mineral particles. Divalent metals ( $\mathrm{Co}, \mathrm{Ni}, \mathrm{Mn})$ and $\mathrm{Sr}$ constitute the second labile group of elements, yet this group also comprises low-mobility $\mathrm{Fe}$ and $\mathrm{Cr}$. The third group of insoluble low-mobility elements is marked by the presence of phosphates (REEs and $\mathrm{P}$ ), refractory $\mathrm{Zr}$, and volatile $\mathrm{Pb}$. The fifth 

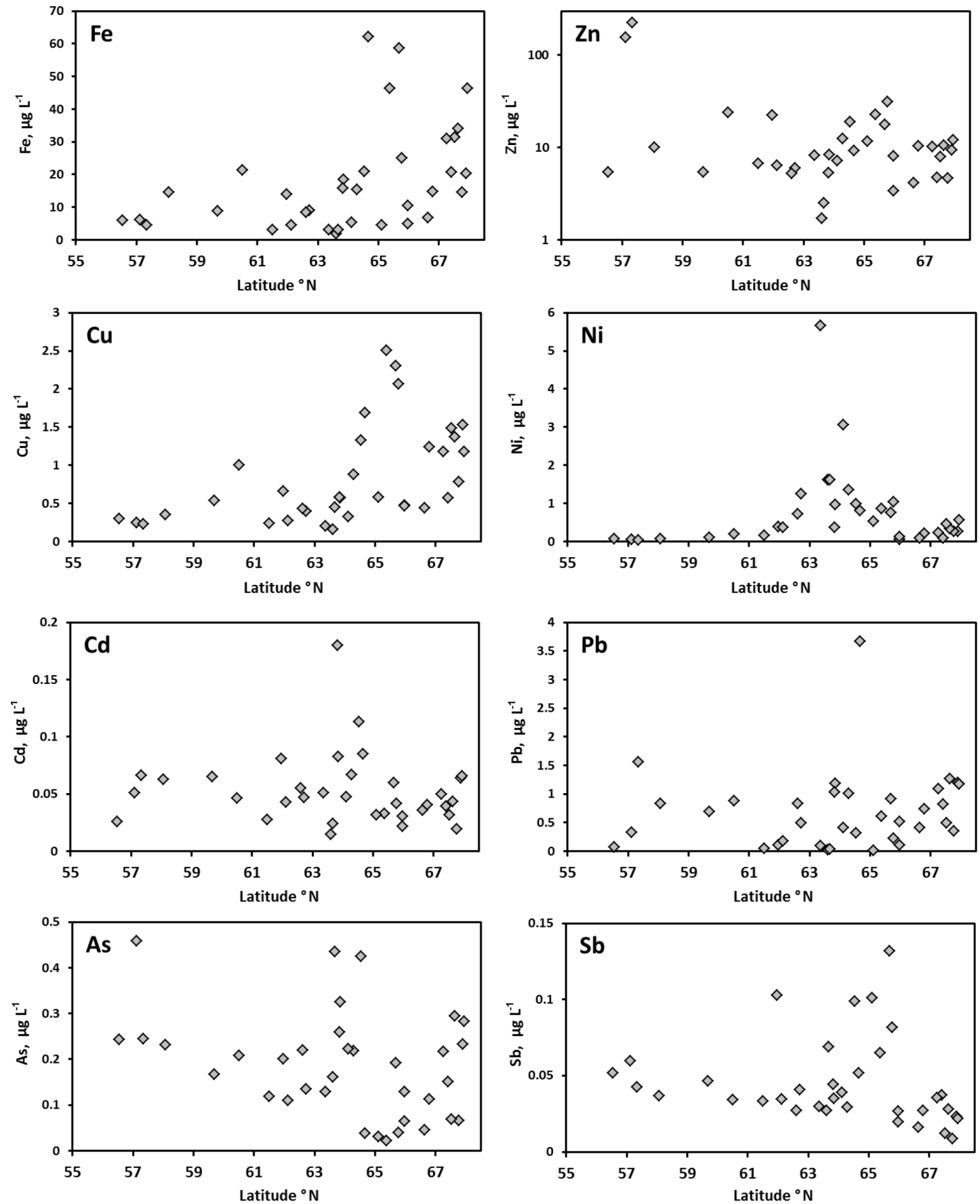

Figure 2. Examples of dissolved $(<0.45 \mu \mathrm{m})$ metal concentrations in snow water as a function of latitude. The cause for the elevated concentrations of $\mathrm{Ni}, \mathrm{Cd}$ and $\mathrm{Sb}$ at ca. $64-65^{\circ} \mathrm{N}$ is most likely industrial impact, but given relatively low number of data points around industrial centers it is hard to prove it unambiguously.

group of elements revealed by HCA of particles is composed of $\mathrm{Sb}, \mathrm{Cu}$ and $\mathrm{Zn}$. All these elements are strongly enriched in snow particles over the soil minerals (see Fig. 6a). The last group of elements in snow particles comprises both labile (Li) and biologically important $\mathrm{Mo}, \mathrm{K}, \mathrm{Rb}, \mathrm{Ba}$ and toxic volatile elements which could bear the signature of anthro- pogenic pollution (As, $\mathrm{Cd}$ ) but also low-mobility $\mathrm{Ti}$ and $\mathrm{Ga}$. We could not identify the link of elements in this group to the degree of snow particle enrichment relative to main "local" substrates of the WSL (moss, peat and clays), shown in Fig. 6. 


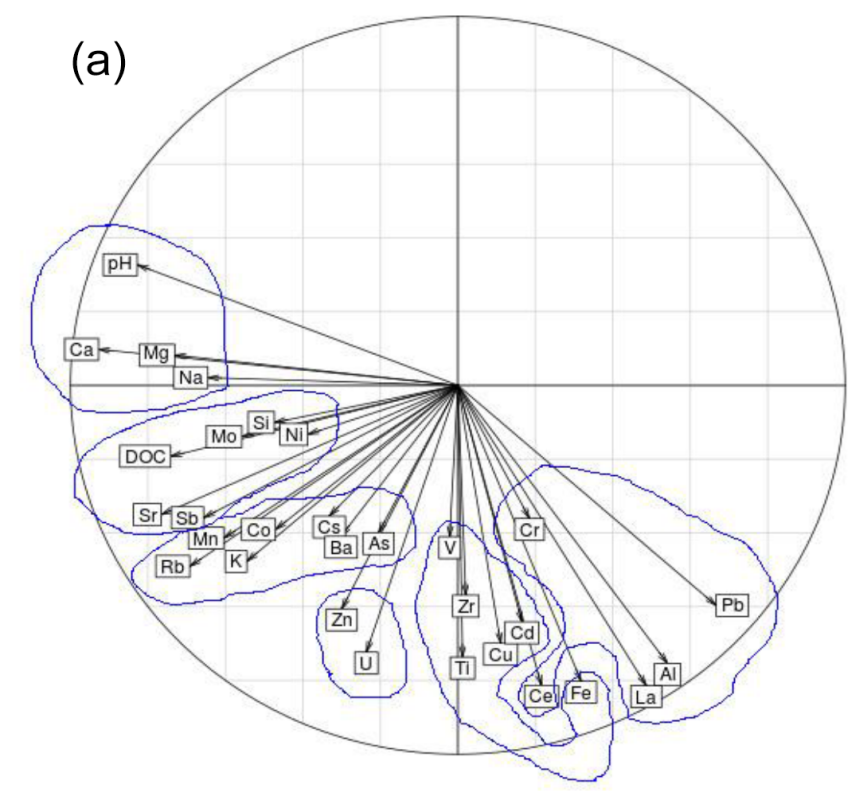

Dissolved fraction

(b) Cluster dendrogram

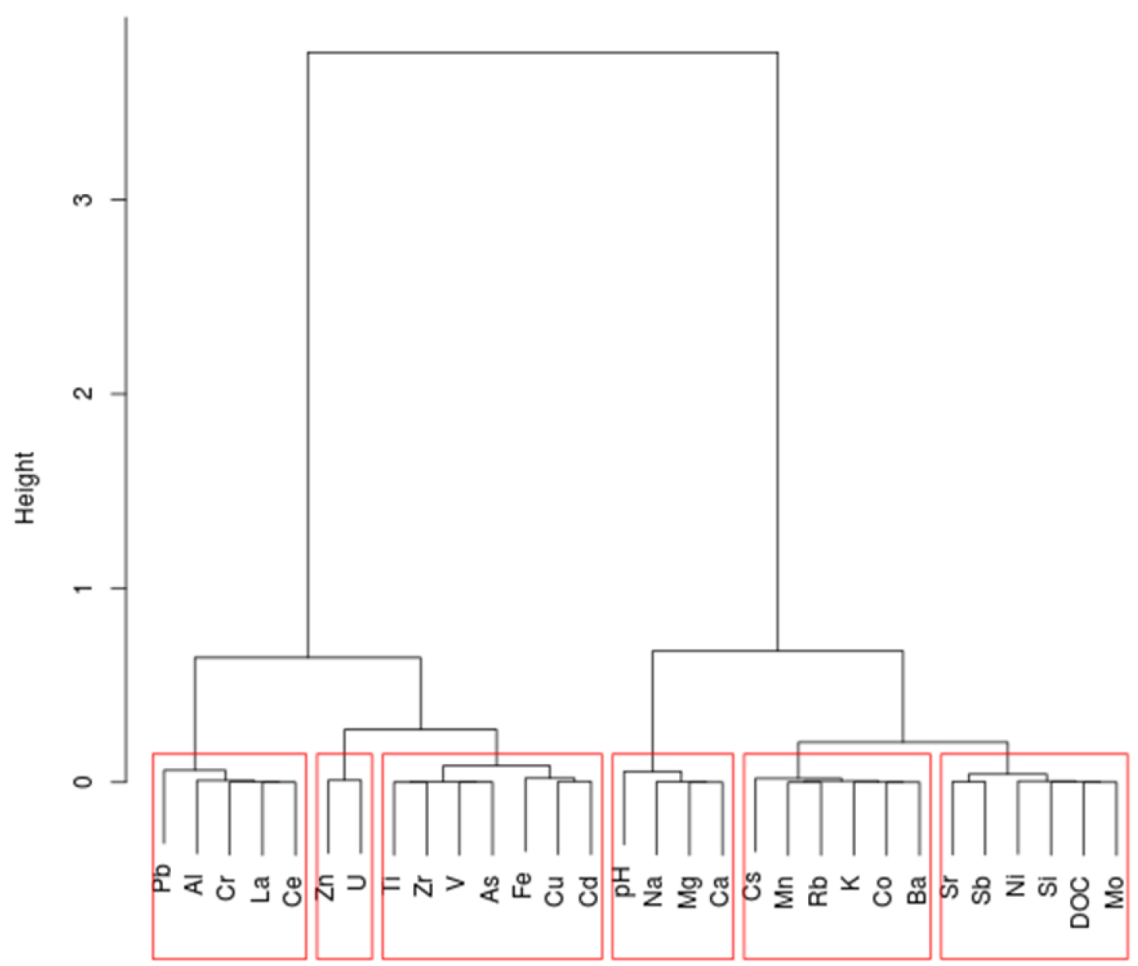

Dissolved fraction

Figure 3. (a) PCA factorial map F1 $\times$ F2 of elements of a reconstructed table for the dissolved fraction. Partitioning of elements into six groups revealed by HCA is shown by a contour line. (b) Dendrogram of a hierarchical cluster analysis (HCA) performed on variables of a reconstructed table for the dissolved fraction using the Pearson correlation as a distance measure and Ward's method for the linkage rule. 

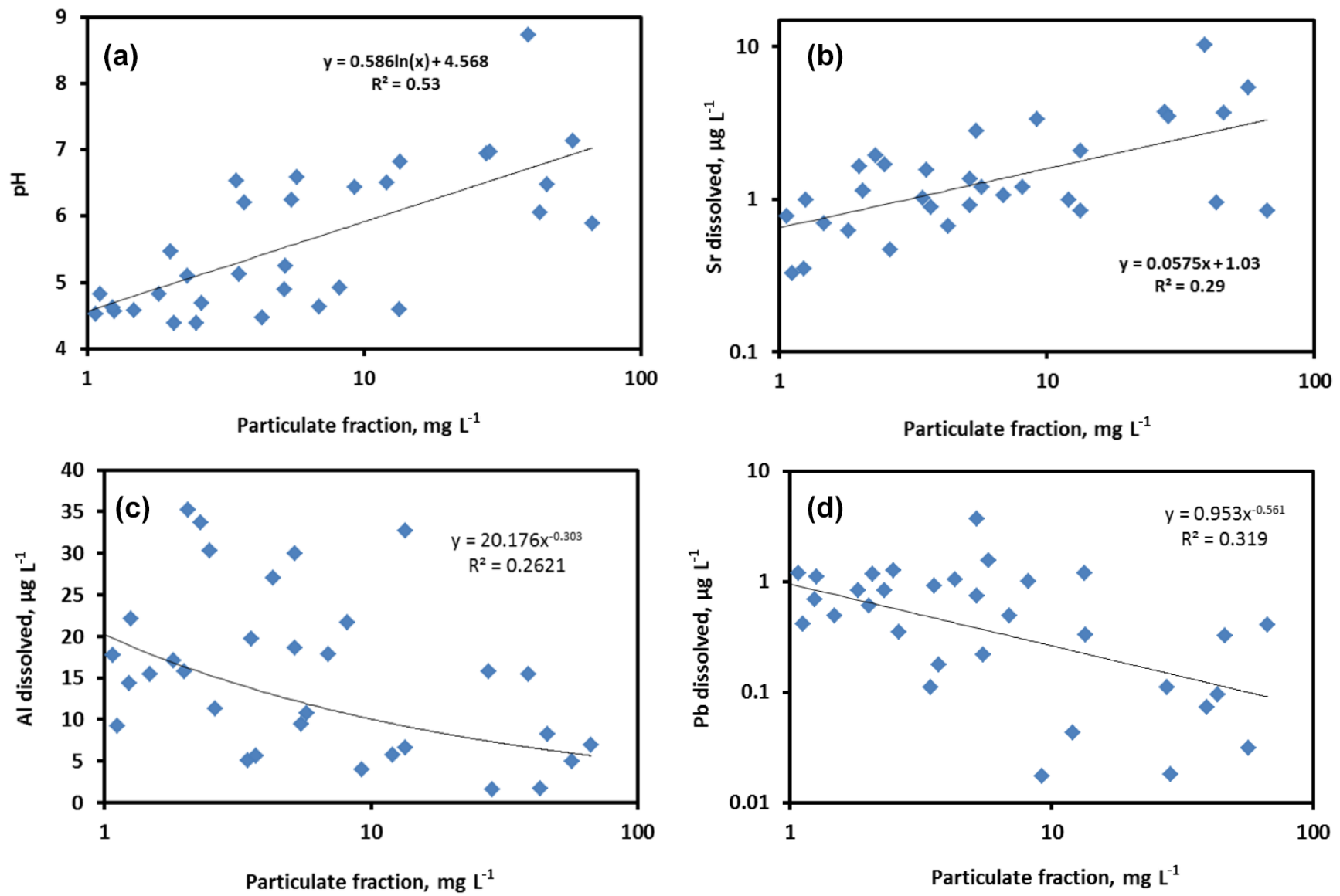

Figure 4. $\mathrm{pH}$ value (a) and $\mathrm{Sr}(\mathbf{b}), \mathrm{Al}(\mathbf{c})$ and $\mathrm{Pb}(\mathbf{d})$ concentration in dissolved fraction of snow as a function of concentration of particles. Note $\log X$ scale for $\mathrm{Sr}$ and $\mathrm{Pb}$.

\subsection{Possible impact of snow deposition on major and trace elements in lakes and rivers}

\subsubsection{Snow water in comparison to lake and river water}

The concentrations of dissolved major and trace elements in the snow water fraction can be compared with those in thermokarst (thaw) lakes of western Siberia measured in 2013-2014. These lakes are shallow (0.5-1.5 m depth) water bodies representing the largest reservoir of surface waters in western Siberia, north of $62^{\circ} \mathrm{N}$ (Polishchuk et al., 2017). The average concentration of major and trace elements in thermokarst lakes of various size (Manasypov et al., 2014) can be compared with those in snow water collected in this study across the same latitudinal gradient. Because the size of thermokarst lakes of the WSL ranges from a few square meters to several square kilometers, four representative ranges of lake diameters are used for this comparison $(0-10,11-$ $100,101-500$ and $>500 \mathrm{~m}$ ). Given that the springtime lake concentrations across the latitudinal gradient are not available, the summertime elementary compositions of lakes were taken as most representative for the open water period of the year. The concentrations of low-soluble elements such as Fe, $\mathrm{Al}$, trivalent and tetravalent hydrolysates in lakes are 1 to 2 orders of magnitude above their concentrations in snow (not shown). At the same time, $\mathrm{Zn}, \mathrm{Cu}, \mathrm{Cd}, \mathrm{Pb}, \mathrm{Sb}$ and $\mathrm{Mo}$ exhibited snow water concentrations that were comparable to or significantly higher $(p<0.05)$ than the concentrations in lakes.

Because the main source of water in shallow lakes of the WSL in spring is melted snow (Manasypov et al., 2015), we could compare the mean concentrations of snow water with spring-period lake water concentration for one particular region of discontinuous permafrost zone (town of Nojabrsk, Khanymey site) for which high-resolution seasonal observations on lakes of various size are available. For two classes of lake size $\left(<0.5\right.$ and $\left.>0.5 \mathrm{~km}^{2}\right)$, the following three groups of elements could be distinguished. The concentrations of dissolved $\mathrm{Na}, \mathrm{Mn}, \mathrm{Zn}, \mathrm{As}, \mathrm{Rb}$ and $\mathrm{Sr}$ in snow water are similar (within a factor of 2) to lake water concentrations. Concentrations of DIC, $\mathrm{Cl}, \mathrm{SO}_{4}, \mathrm{Mg}, \mathrm{Ca}, \mathrm{Cr}, \mathrm{Co}, \mathrm{Ni}, \mathrm{Cu}, \mathrm{Mo}, \mathrm{Cd}$, $\mathrm{Sb}, \mathrm{Cs}, \mathrm{W}, \mathrm{Pb}$ and $\mathrm{U}$ in snow are close or higher $(p<0.05)$ than those in lakes. Finally, concentrations of DOC, Al, Si, $\mathrm{K}, \mathrm{Ti}, \mathrm{V}, \mathrm{Fe}, \mathrm{Ga}, \mathrm{Zr}, \mathrm{Ba}$, and REEs in snow water are sig- 

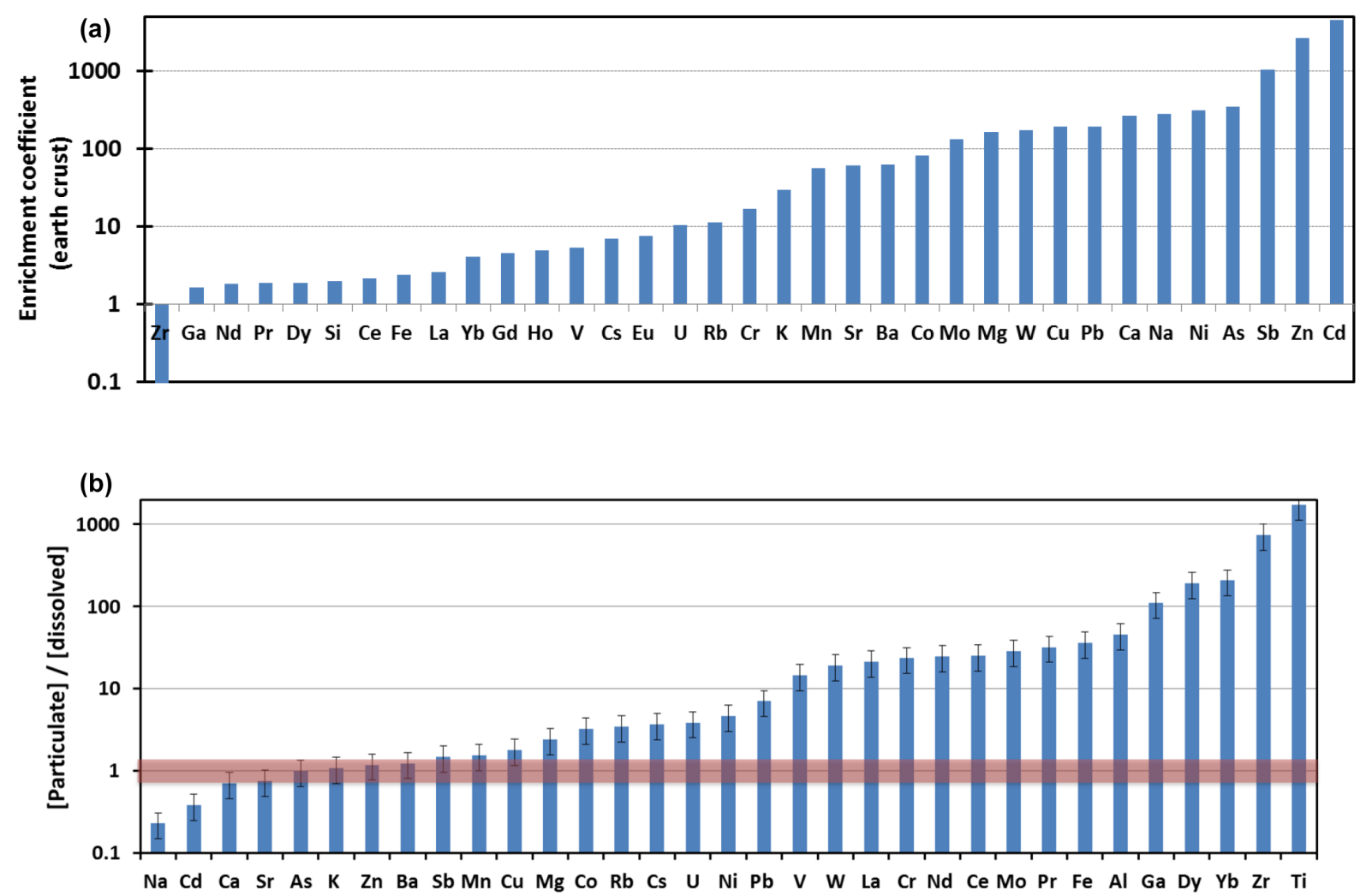

Figure 5. (a) The latitude-averaged Al-normalized enrichment coefficients of snow particles with respect to the Earth crust. (b) The average values $\left(56\right.$ to $\left.68^{\circ} \mathrm{N}\right)$ of the ratio of particulate to dissolved element concentration in snow water of western Siberia. The bold red line indicates statistically non-significant deviation from 1 .

nificantly lower than the lakes' concentrations. There was no distinction of elements belonging to individual groups of the HCA and this classification.

The concentrations of elements in snow water could be also compared with river water concentrations measured during the spring flood of 2014 across the full latitudinal profile, since such data for rivers of different sizes are available (Pokrovsky et al., 2015, 2016a). Examples of elements whose concentrations in snow water are higher or comparable with those in rivers during spring flood are illustrated in Fig. S3. Generally, the effect of snowmelt is mostly pronounced north of $64^{\circ} \mathrm{N}$. During this period, when the rivers are essentially fed by melted snow, the atmospheric deposition exhibited comparable or higher $(p<0.05)$ concentrations of $\mathrm{SO}_{4}, \mathrm{Cr}, \mathrm{Co}, \mathrm{Ni}, \mathrm{Cu}, \mathrm{Zn}, \mathrm{Mo}, \mathrm{Cd}, \mathrm{Sb}, \mathrm{Cs}, \mathrm{W}$ and $\mathrm{Pb}$ than those in rivers. These elements belonged to five dominant groups of HCA treatment. The concentrations of all other elements in WSL rivers cannot be solely explained by snow water concentration.

Note that, by filtering the snow and the lake/river water to $0.45 \mu \mathrm{m}$, the dissolved fraction includes a colloidal load, which can play a crucial role in the concentration of trace elements (Pokrovsky et al., 2016b). However, with typical concentration of DOC in snow water around $1-2 \mathrm{mg} \mathrm{L}^{-1}$, the share of colloidal forms of metals will be an order of magnitude lower than that in rivers and lakes of the WSL, which have 10 to $30 \mathrm{mg} \mathrm{L}^{-1}$ of DOC.

\subsubsection{Comparison of river fluxes in spring and snow water stock}

Considering the mass balance calculation of snowmelt influence on element fluxes in WSL rivers, the ratios of river fluxes in May-June to snow stock can be presented in the form of histograms for three latitudinal zones (Fig. 7). These ratios systematically decrease with the increase in the latitude. In the southern, permafrost-free zone, $\mathrm{Zn}, \mathrm{Cd}, \mathrm{Pb}, \mathrm{Ga}$, $\mathrm{Cs}, \mathrm{W}, \mathrm{Sb}$ and $\mathrm{Cl}$ fluxes in rivers can be provided essentially by snowmelt. The riverine fluxes of DIC, $\mathrm{Cl}^{-}, \mathrm{SO}_{4}^{2-}, \mathrm{Na}$, $\mathrm{Mg}, \mathrm{Ca}, \mathrm{Sr}, \mathrm{Rb}, \mathrm{Cs}, \mathrm{Zn}, \mathrm{Cu}, \mathrm{Cr}, \mathrm{Ni}, \mathrm{Cu}, \mathrm{Pb}, \mathrm{As}, \mathrm{Sb}, \mathrm{Mo}$, $\mathrm{W}$ and $\mathrm{U}$ are strongly (i.e., $\geq 50 \%$ at $p<0.05$ ) affected by snowmelt in the discontinuous and continuous permafrost zones, north of $60-62^{\circ} \mathrm{N}$.

According to the evolution of the ratio [river flux] / [snow stock] with the latitude, three groups of elements can be distinguished: (i) elements that steadily decrease this ratio suggesting an increase in the impact of snowmelt northward: $\mathrm{DOC}, \mathrm{SO}_{4}, \mathrm{Al}, \mathrm{Ti}, \mathrm{V}, \mathrm{Cr}, \mathrm{Rb}, \mathrm{Sr}, \mathrm{Cd}, \mathrm{Sb}, \mathrm{Cs}, \mathrm{La}, \mathrm{Ce}$, 

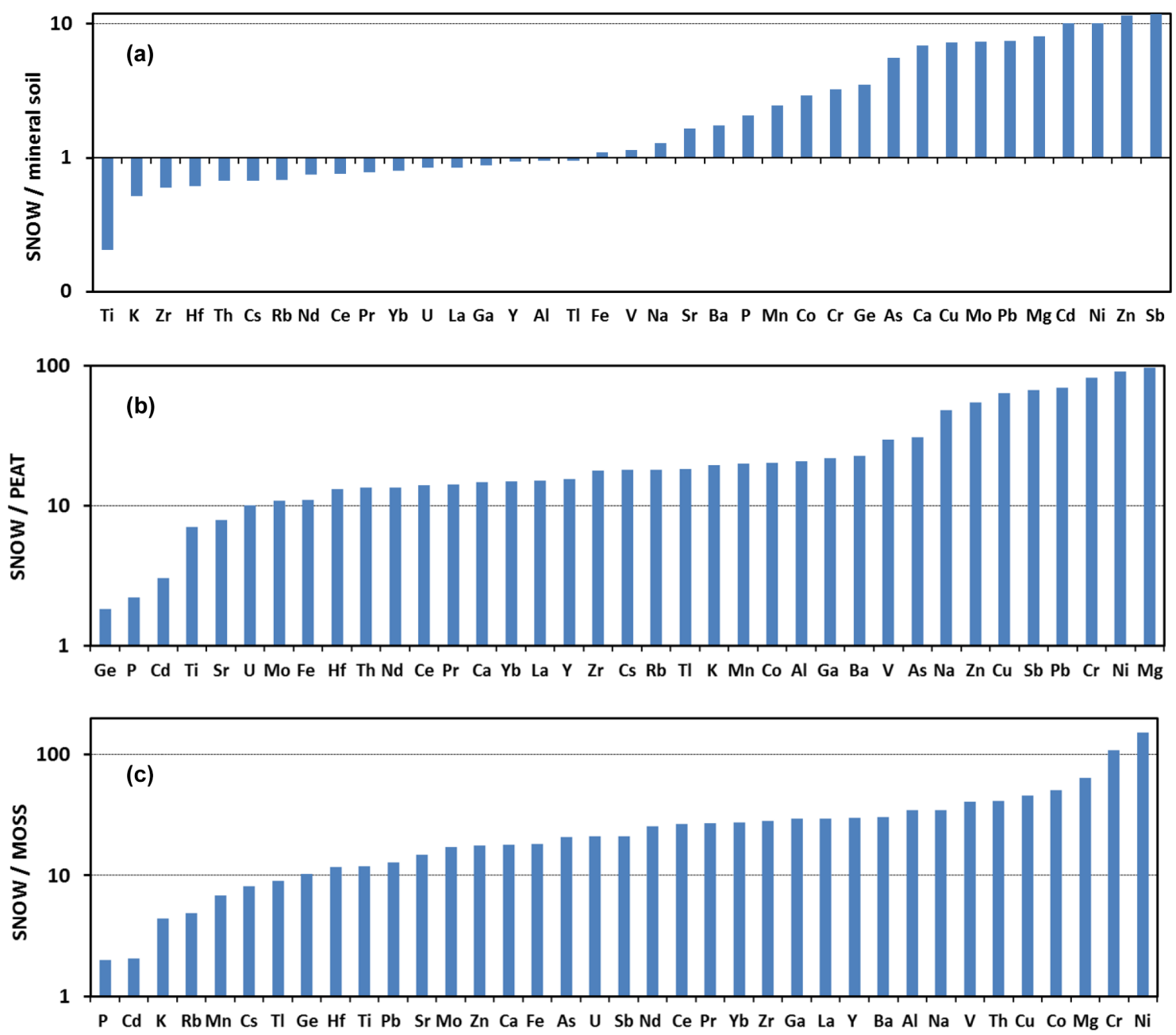

Figure 6. The ratios of the average concentrations of elements in snow particles (neglecting sample SF22) to those in mineral soil (a), peat (b) and mosses (c) of the WSL. The peat, moss, and underlying mineral horizons data are averaged over the latitude of 55 to $68^{\circ} \mathrm{N}$ as described in Stepanova et al. (2015). Note normal $Y$ scale for mineral soil (a) and $\log Y$ scale for peat and moss (b, c).

$\mathrm{W}, \mathrm{Pb}$; (ii) elements for which this ratio decreases abruptly to $62 \pm 2^{\circ} \mathrm{N}$ and then remains constant further northward: DIC, $\mathrm{Na}, \mathrm{Mg}, \mathrm{Si}, \mathrm{K}, \mathrm{Ca}, \mathrm{Ni}, \mathrm{Cu}, \mathrm{As}, \mathrm{Mo}$ and $\mathrm{U}$; (iii) elements exhibiting non-systematic variation in the ratio with latitude but having strong ( $>50 \%$ ) impact of snowmelt on river fluxes $(\mathrm{Cl}, \mathrm{Co}, \mathrm{Zn}, \mathrm{Ga})$; and (iv) elements having negligible $(<10 \%)$ impact of snowmelt on river fluxes $(\mathrm{Mn}, \mathrm{Fe}$, $\mathrm{Zr}$ and $\mathrm{Ba}$ ). The impact of snowmelt on river export fluxes in spring strongly increases northward for DIC, $\mathrm{Cl}^{-}, \mathrm{SO}_{4}^{2-}$, $\mathrm{Na}, \mathrm{Mg}, \mathrm{Ca}, \mathrm{Cr}, \mathrm{Ni}, \mathrm{Mo}, \mathrm{Rb}$ and $\mathrm{U}$, whereas $\mathrm{Cd}, \mathrm{Pb}, \mathrm{Sb}, \mathrm{Cu}$, As, $\mathrm{W}$ and Cs present a high impact of snowmelt water on river for the three latitude zones (Fig. 7). Although these elements belong to all five major groups of the cluster analysis (Fig. 3b), they can be characterized as soluble (highly labile) elements, originating either from marine aerosols or from leaching from soluble minerals such as carbonates, and also including volatile constituents of the atmospheric aerosols $(\mathrm{Cd}, \mathrm{Pb}, \mathrm{Sb}, \mathrm{As})$.

\section{Discussion}

\subsection{Dissolved major and trace elements in Siberian snow}

In accord with general knowledge on Arctic aerosol chemistry (Barrie, 1986; Barrie and Barrie, 1990; Laing et al., 2014, 2015; Nguyen et al., 2013; Pacyna and Ottar, 1989; Shevchenko et al., 2003; Weinbruch et al., 2012), the principal component structure of snow water chemistry identified the combination of lithogenic source (dust and soil particles dissolution, providing low-mobility, insoluble elements such as $\mathrm{Al}, \mathrm{Fe}, \mathrm{Cr}, \mathrm{Zr}, \mathrm{REEs}$ ) and marine aerosols (soluble forms, providing high concentrations of mobile elements such as $\mathrm{Ca}, \mathrm{Mg}, \mathrm{Na}, \mathrm{Mo}, \mathrm{Ni}$ ). The latter may also originate from aeolian transport of carbonate-rich soils. The biogenic component includes $\mathrm{Mn}, \mathrm{Zn}, \mathrm{K}, \mathrm{Rb}, \mathrm{DOC}$ and $\mathrm{Si}$, whereas the anthropogenic pollution originates from coal combustion 

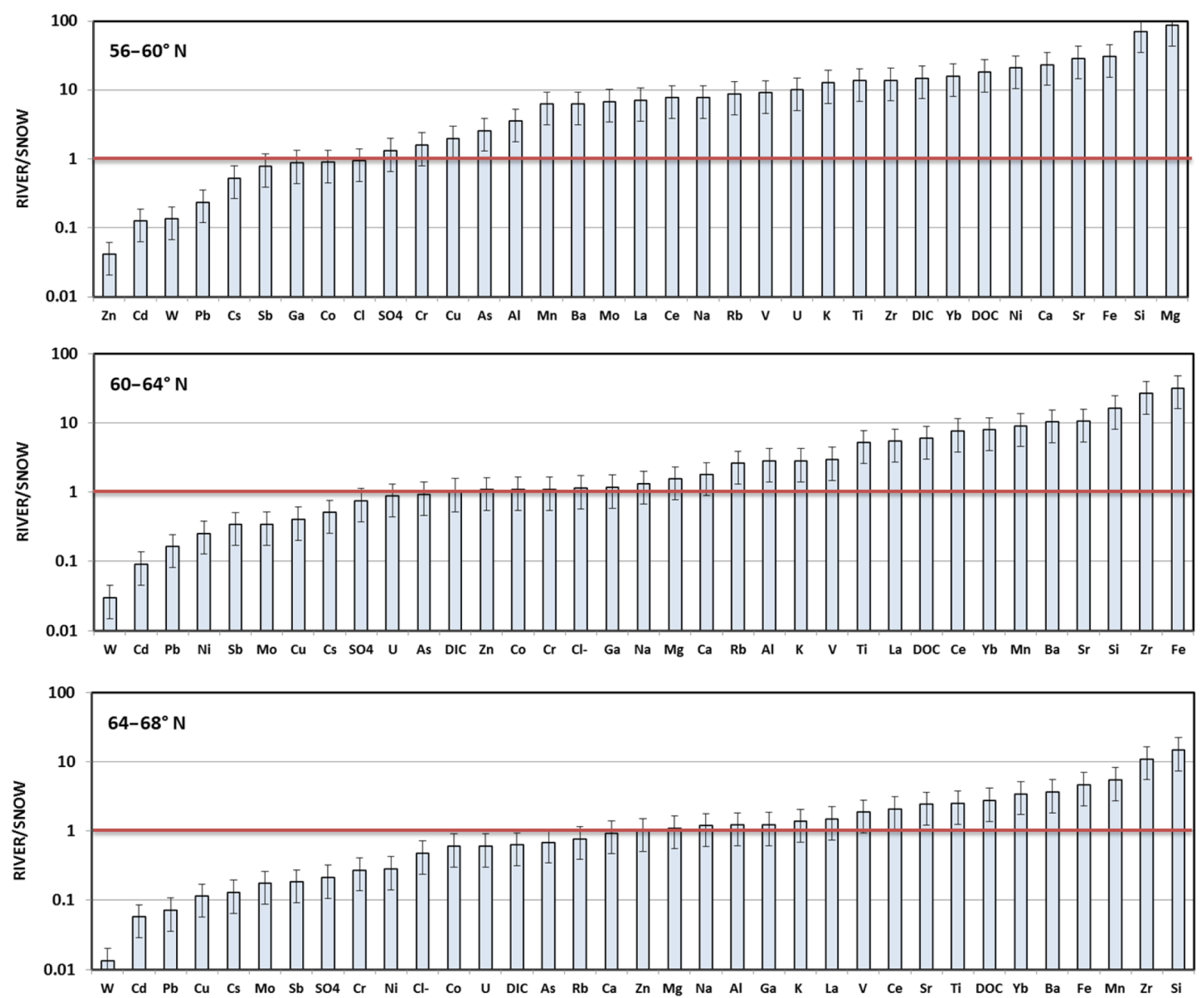

Figure 7. The ratio of mean dissolved flux of rivers in three latitudinal zones (56-60, 60-64, and $\left.64-68^{\circ} \mathrm{N}\right)$ of the WSL to the stock of dissolved fraction of snow. For this calculation, the snow volume (in millimeters of water) accumulated over full winter and mean river runoff over May and June were used. The impact of snowmelt on river export fluxes in spring strongly increases northward for DIC, $\mathrm{Cl}^{-}$, $\mathrm{SO}_{4}^{2-}, \mathrm{Na}, \mathrm{Mg}, \mathrm{Ca}, \mathrm{Cr}, \mathrm{Ni}, \mathrm{Mo}, \mathrm{Rb}$ and $\mathrm{U}$, whereas $\mathrm{Cd}, \mathrm{Pb}, \mathrm{Sb}, \mathrm{Cu}, \mathrm{As}, \mathrm{W}$ and $\mathrm{Cs}$ present a high impact of snowmelt water on river for the three latitude zones.

( $\mathrm{Sb}, \mathrm{Co}$ ) and heating systems, gas flaring at the gas oil production site, and non-ferrous metal-smelter industry ( $\mathrm{Sb}, \mathrm{Zn}$, Vinogradova et al., 1993) and ground transportation $(\mathrm{Pb}, \mathrm{Cu}$, Zn, Cr, Ni, As; Rossini Oliva and Fernández Espinosa, 2007; Sutherland et al., 2000).

The soluble, highly mobile elements such as alkali and especially alkaline-earth elements, $\mathrm{Sb}, \mathrm{Mo}, \mathrm{W}$ and $\mathrm{U}$ demonstrated an increase in their dissolved $(<0.45 \mu \mathrm{m})$ concentration with the increase in the total particulate fraction (Fig. 4b). We interpret this increase in concentration, also correlated with $\mathrm{pH}_{\text {snow water }}$ increase (Fig. $4 \mathrm{a}$ ), as a result of element leaching from soluble minerals such as calcite and dolomite. There was a positive $\left(R^{2}=0.53, p<0.05\right)$ correla- tion between the percentage of calcite in the particulate fraction of snow and $\mathrm{Ca}$ concentration in snow meltwater (not shown). Therefore, we hypothesize that simultaneous mobilization of carbonate minerals and soluble elements from the soil and rocks to the atmosphere occurs in southern, carbonate-rock bearing provinces where the winter aerosols are generated. The generation of insoluble elements such as trivalent and tetravalent hydrolysates in dissolved fraction of snow occurs independently of snow enrichment in solid particles. Indeed, the decrease, and not the increase, in insoluble elements dissolved concentration with the increase in particle concentration (Fig. 4c, d) suggests that these elements are not desorbed or leached from mineral particles, either within the 
origin of aerosol formation or during snow melting and filtration in the laboratory. Alternatively, these elements can be linked to specific labile pools that constitute the mineral fraction. Unfortunately, we could not run selective extractions on very small amounts of solid particles in WSL snow available in this study.

Regional background concentrations of dissolved metals in snow of Québec (Canada) are reported to be 1.1, 1.7, and $1.6 \mu \mathrm{g} \mathrm{L}_{\text {meltwater }}^{-1}$ for $\mathrm{Cu}, \mathrm{Pb}$, and $\mathrm{Zn}$, respectively (Telmer et al., 2004). The values for $\mathrm{Cu}$ and $\mathrm{Pb}$ are comparable with average snow water concentration across the WSL $(0.83$ and 0.68 , respectively), but the concentration of $\mathrm{Zn}$ in the WSL snow is significantly higher $\left(10.1 \pm 5.0 \mu \mathrm{g} \mathrm{L}^{-1}\right.$, excluding three contaminated samples near Tomsk). Background concentrations of dissolved $\mathrm{Cu}, \mathrm{Pb}$, and $\mathrm{Zn}$ in snow of the Alaskan Arctic are much lower (0.08, 0.09 and 1.2, respectively; Snyder-Conn et al., 1997). In snow from background areas of northeastern European Russia, the concentrations of dissolved $\mathrm{Cu}$ are nearly at the same level as in snow from the WSL, whereas the concentrations of dissolved $\mathrm{Pb}$ and $\mathrm{Zn}$ are 2 times lower (Walker et al., 2003). Concentrations of dissolved $\mathrm{Cu}$ and $\mathrm{Zn}$ in snow of NW Finland are a few times lower than in snow of the WSL; concentrations of dissolved $\mathrm{Pb}$ are at the same level (de Caritat et al., 1998).

Significant enrichment in $\mathrm{Ni}$ is known for the aerosols of the Arctic Ocean (Shevchenko et al., 2003). It may be linked to not only Ni transport from Norilsk and Kola smelters but also to Ni fractionation at the sea surface (Duce et al., 1976). $\mathrm{Ni}$ concentration in snow water of the northern part of the WSL significantly exceeds that in the thermokarst lakes. The winter snow stock of dissolved $\mathrm{Ni}$ is several times higher than the river export of this element during spring floods in the permafrost-bearing zone of the WSL, north of $60^{\circ} \mathrm{N}$, and $\mathrm{Ni}$ concentrations in snow particles exceed its concentrations in moss and peat of the territory by up to 2 orders of magnitude.

The wintertime deposition of dissolved $(<0.45 \mu \mathrm{m})$ metals on the surface of northern part of the WSL can be calculated taking into account the mean multi-annual volume of accumulated snow during 8 winter months (in millimeters of snow water) and the average concentration of elements in February snow collected north of $64^{\circ} \mathrm{N}$. The monthly depositions of selected metals $\left(\mu \mathrm{g} \mathrm{m}^{-2}\right.$ month $\left.^{-1}\right)$ on the north of the WSL in the form of snow are equal to $2.8,12,15,210$ and 0.9 for $\mathrm{As}, \mathrm{Ni}, \mathrm{Pb}, \mathrm{Zn}$, and $\mathrm{Cd}$, respectively, which is significantly higher than the values for winter deposition of insoluble aerosols in the Russian Arctic (0.22, 0.74, 2.7, 1.3 and 0.056, respectively; Shevchenko et al., 2003). Only V exhibited similar values of Arctic aerosol and snow deposition (0.71 and $0.96 \mu \mathrm{g} \mathrm{m}^{-2}$ month $^{-1}$, respectively).

\subsection{Particulate forms of elements in the snow across the latitudinal profile: the effect of mineralogical substrate, industrial centers, local pollution and long-range transport}

The majority of elements are transported in particulate rather than dissolved fraction in the snow water (Fig. 5b). This is in general agreement with the results of other studies in Scandinavia and Kola Peninsula (Reimann et al., 1996), northeastern European Russia (Walker et al., 2003) and on drifting ice in the northern Barents Sea (Gordeev and Lisitzin, 2005). The enrichment of the snow particulate fraction relative to the Earth crust as shown by the Al-normalized enrichment coefficient (Figs. 5a, S1) can be understood via taking into account the particle concentration in snow and microscopic observations. We suggest that the clays supply most trace elements in the PF. The atmospheric particles are known to exert a significant impact on soils and ground vegetation (KabataPendias and Pendias, 1984; Rasmussen, 1998; Steinnes and Friedland, 2006). In the case of the WSL, the elementary composition of the snow particulate fraction was compared with three main reservoirs of elements within the soil, sampled over a significant latitudinal profile, from 55 to $68^{\circ} \mathrm{N}$ (Stepanova et al., 2015). These reservoirs are averaged over the complete latitudinal range and include (i) mineral fraction from the bottom of the peat column; (ii) depth-averaged peat column composition; and (iii) Sphagnum mosses, collected in ombrotrophic bogs, which receive their constituents essentially from the atmosphere (e.g., Santelman and Gorham, 1988).

The particularity of the northern part of the western Siberia lowland is that the active (seasonally unfrozen) soil layer is located within the organic (moss + peat) rather than mineral horizon; the latter is represented by poorly reactive sands and clays (Baulin et al., 1967; Baulin, 1985; Tyrtikov, 1973, 1979). As a result, surface waters essentially drain the organic part of the column, which is very poor in lithogenic elements (Pokrovsky et al., 2015, 2016a). The supply of mineral particles from the snow therefore may significantly enrich the rivers and lakes in dissolved alkaline earth metals $(\mathrm{Mg}, \mathrm{Ca}$, $\mathrm{Sr}, \mathrm{Ba})$, phosphorus and other elements given high reactivity of incoming silicate and carbonate grains in acidic $(\mathrm{pH}<3-$ $4)$, organic-rich $\left(10<\mathrm{DOC}<50 \mathrm{mg} \mathrm{L}^{-1}\right)$ surface waters of western Siberia. The degree to which such a supply can lead to overestimation of the calculated chemical weathering export fluxes of cations in the permafrost zone is impossible to quantify. Therefore, in view of the importance of atmospheric input of solid particles for mineral-poor peat bogs of western Siberia, the seasonal, year-round measurements of particulate atmospheric deposition in this region are necessary.

The main source of mineral particles in the southern part of the latitudinal profile $\left(56-58^{\circ} \mathrm{N}\right)$ may be soils of steppe and forest-steppe regions south of the WSL, where the land is cultivated and the snow cover is relatively thin. The ae- 
olian transport of soil particles under these conditions may be efficient even in winter (Evseeva et al., 2003). The main source of ash particles in the southern part of the profile is the industry and transport of the city of Tomsk (Boyarkina et al., 1993; Yazikov et al., 2000; Talovskaya et al., 2014). The concentration of particles in snow collected from 58 to $61^{\circ} \mathrm{N}$ ranged between 0.85 and $5.7 \mathrm{mg} \mathrm{L}^{-1}$, which is comparable to or slightly higher than the values reported for the Arctic snow cover (Darby et al., 1974; Mullen et al., 1972; Nürnberg et al., 1994; Shevchenko et al., 2002, 2010). It is important to note that in this zone of low PF concentration, combustion spheres, fly ash and black carbon a few micrometers in diameter were dominant. This can explain the relatively low concentrations of all TEs at low PF concentration, as carbon compounds likely contain very low proportions of trace metals. The most important sources of fly ash and black carbon are gas flaring, land transport, heating plants, residential combustion, forest fires (mainly in summer) and industrial plants (Moskovchenko and Babushkin, 2012; Quinn et al., 2008; Stohl et al., 2013). Chemical pollution of the atmosphere during gas flaring associated with oil industry is known for the WSL (Raputa, 2013; Yashchenko et al., 2014). The black carbon produced during gas burning is detected not only in western Siberia but also in the Russian sector of the Arctic Ocean at high latitudes (Stohl et al., 2013; Evangeliou et al., 2017).

In the zone $62-64.5^{\circ} \mathrm{N}$, where some impact of oil industry is possible, the concentrations of insoluble particles in snow were above $10 \mathrm{mg} \mathrm{L}^{-1}$, achieving the value of $66.6 \mathrm{~m} \mathrm{~L}^{-1}$ in sample SF36. Backward trajectories to this site using the Draxler and Rolf (2003) approach show that, during the last few days before sampling, the air masses arrived from southwestern direction. Accordingly, the particulate fraction in these samples contained mostly mineral particles $1-25 \mu \mathrm{m}$ size with some fly ash (burning spheres). It is possible that mineral particles are supplied here via long-range transport from forest-steppe, steppe and semi-desert regions south and southwest from the study site. Indeed, during the winter snow coverage period, the dominant winds in this zone have S, SW and W directions (Moskovchenko and Babushkin, 2012). The events of mineral dust transport over large distances are well known in the boreal zone (Lisitzin, 1978, 2011; Shevchenko et al., 2010).

Further north of the studied latitudinal profile, from 65 to $68^{\circ} \mathrm{N}$, the concentration of snow particles ranged from 0.8 to $9.2 \mathrm{mg} \mathrm{L}^{-1}$. These values are within the background in the Arctic and subarctic (Darby et al., 1974; Mullen et al., 1972; Nürnberg et al., 1994; Shevchenko et al., 2002). The particulate fraction was represented by mineral debris of 1 to $15 \mu \mathrm{m}$ in size, with frequent but not significant presence of spherical ash particles, biogenic strains and porous carbon particles. Because the main source of mineral particles is long-range transport from southern desert and steppe regions, moving to the north decreases the influence of these provinces.
We believe that the elevated concentrations of divalent metals, As and $\mathrm{Sb}$ in snow particles (Figs. 5a, S1) should not be interpreted as necessarily pollution from the industrial centers. Rather, volatile $\mathrm{Cd}, \mathrm{Pb}$ and $\mathrm{As}$ may originate from long-range transport of desert material. Therefore, we attempted to distinguish the well-known refractory, non-volatile heavy metals such as $\mathrm{Cu}, \mathrm{Ni}$ and $\mathrm{Co}$ and more volatile elements such as $\mathrm{Pb}, \mathrm{Cd}$ and As (i.e., Reimann et al., 2000) based on the HCA treatment. For both particulate and dissolved fractions, these elements are located in three or two different groups but never belong to one single group of inter-correlated elements. As such the available data do not evidence similar origins of $\mathrm{Cu}, \mathrm{Ni}$ and $\mathrm{Co}$, or $\mathrm{Pb}, \mathrm{Cd}$, and $\mathrm{As}$ in the snapshot of the WSL snow sampled in this work.

\subsection{Impact of snow on hydrochemistry of inland waters and riverine elementary fluxes}

Quantitative comparison of element input to the land surface with winter snow and element concentrations and fluxes in the WSL inland waters provided the assessment of minimal atmospheric contribution to lake storage and river export. The concentrations of $\mathrm{Pb}, \mathrm{Zn}, \mathrm{Cu}, \mathrm{Cd}, \mathrm{Sb}$ and $\mathrm{Mo}$ in lakes are significantly lower than those in snow. However, these elements belong to four various groups of elements in dissolved snow fraction, identified by the HCA (Fig. 3b). In rivers, $\mathrm{SO}_{4}, \mathrm{Cr}, \mathrm{Co}, \mathrm{Ni}, \mathrm{Cu}, \mathrm{Zn}, \mathrm{Mo}, \mathrm{Cd}, \mathrm{Sb}, \mathrm{Cs}, \mathrm{W}$ and $\mathrm{Pb}$ are dominated by snow input. These elements also belong to four various groups of the HCA. It thus can be concluded that there is no direct link between the group of elements identified by the cluster dendrogram in the snow water and the elements whose concentrations in rivers or lakes are significantly affected by snow deposition. We believe that a natural cause of this apparent inconsistency relates to different mechanisms controlling the element distribution in the aerosols and surface waters. Whereas the aerosols are influenced by local sources of pollution, remote desert provinces, and leaching of soluble elements from mineral particles, the inland water chemical composition is controlled by interaction of melted snow with upper peat and moss/lichen horizons, underground feeding, and release of elements from suspended matter due to abrasion of river banks in spring flood.

Overall, the impact of the snowmelt on chemical composition of western Siberian thermokarst lakes may be very high. This will be further accentuated by the reported increase in the proportion of meltwater that does not reach the main rivers but is stored by the wetlands (i.e., from $20-30 \%$ in early 1990 s to $50-60 \%$ in the mid-2000s; Zakharova et al., 2011). A comparison of snow stock-river water fluxes demonstrates that the influence of atmospheric deposition increases northward (Fig. 7). At the same time, the chemical composition of the snow water, although subject to significant variation, does not exhibit any systematic trend with the latitude (Fig. 2) as also follows from the PCA (Sect. 3.1). The reason for this difference may be the rela- 
tively low fluxes and concentrations in rivers of the northern, permafrost-affected territory of the WSL compared to the southern, permafrost-free zone (Pokrovsky et al., 2015, 2016a). As a result, the impact of atmospheric deposition on the riverine transport is more pronounced in the permafrost zone than in the permafrost-free zone. We expect that the contribution of atmospheric deposition into river water fluxes should be quite strong for all flat bog tundra areas of northern Eurasia, including, in addition to the northern part of western Siberia $\left(\sim 400000 \mathrm{~km}^{2}\right)$ studied in this work, the Yamal and Gyda peninsulas (122000 and $160000 \mathrm{~km}^{2}$, respectively), the North Siberian Lowland $\left(\sim 700000 \mathrm{~km}^{2}\right)$, the Kolyma Lowland $\left(170000 \mathrm{~km}^{2}\right)$, and the Yana-Indigirka Lowland $\left(180000 \mathrm{~km}^{2}\right)$ with an overall territory close to 1.7 million $\mathrm{km}^{2}$. The impact of snow deposition on river elementary fluxes should be much lower in permafrost-bearing mountainous terrain such as central and eastern Siberia, the Alaskan slopes, north of the Scandinavian shield and the Canadian High Arctic. In those territories, two factors may decrease the contribution of snow deposition to river fluxes: (1) the impact of local mineral dust for aerosols generation may be well pronounced and (2) the chemical weathering occurs within the mineral seasonally unfrozen layer, producing higher fluxes of inorganic components.

In contrast, in the lowlands of northern Eurasia, the rivers drain essentially organic layer (peat bog) terrain; thus, mineral feeding of rivers is very low. As demonstrated in Sect. 3.3.2 of this study, low chemical (cationic) weathering in the north of the WSL during spring suggests that total dissolved cationic and DIC fluxes in May-June in this and other similar regions are essentially controlled by snowmelt, rather than by soil weathering. It follows that during the spring period, the intensity of chemical weathering in these latitudes can be a factor of 2 (major cations) to 5 (TEs) lower than that deduced from riverine fluxes. However, given that the shares of spring flood period (May-June) in the annual export fluxes are only 5 to $10 \%$ for major cations and 10 to $20 \%$ for TEs (Pokrovsky et al., 2015, 2016a), the overall impact of atmospheric deposits on element export fluxes will be strongly pronounced (i.e., $\geq 50 \%$ of total measured river flux value) only for elements which have the ratio of the springtime river export to snow stock less than 0.2, i.e., $\mathrm{SO}_{4}, \mathrm{Cu}, \mathrm{Mo}, \mathrm{Cd}, \mathrm{Sb}$, $\mathrm{Cs}, \mathrm{W}$ and $\mathrm{Pb}$. With further increase in winter precipitation in western Siberia (i.e., Bulygina et al., 2009), the impact of snowmelt on element transport to the Arctic Ocean by rivers may increase, thus enriching the surface waters in many elements such as $\mathrm{Cd}, \mathrm{Pb}, \mathrm{Sb}, \mathrm{Cr}, \mathrm{Cu}, \mathrm{Ni}, \mathrm{As}, \mathrm{Mo}, \mathrm{Rb}$ and $\mathrm{U}$.

\section{Conclusions}

The chemical composition of surface layer of snow cover was studied across a $1700 \mathrm{~km}$ latitudinal gradient in the WSL. The particulate fraction ranged from 0.4 to $66 \mathrm{mg} \mathrm{L}_{\text {meltwater }}^{-1}$ and increased in the regions of enhanced dust deposition from southern steppe and desert provenances, in the proximity of industrial centers and due to fly ash production from gas burning of the oil exploration sites. There was an increase in the concentration of soluble elements $(\mathrm{Ca}, \mathrm{Mg}, \mathrm{Sr}$, $\mathrm{Mn}, \mathrm{Co}$ ) and $\mathrm{pH}$ in snow water with the increase in mineral (calcite, dolomite) fraction. The elementary composition of $\mathrm{PF}$ demonstrated its significant enrichment in most elements relative to mineral soil horizon, peat and moss across the full latitudinal profile $(\sim 1700 \mathrm{~km})$ of the WSL. As such, solid atmospheric aerosols may be an important factor of insoluble element delivery to the soil surface. The supply of mineral particles from the snow may also significantly enrich the rivers and lakes in dissolved alkaline earth metal micronutrients, phosphorus and other elements given high reactivity of incoming silicate and carbonate grains in acidic $(\mathrm{pH}<3-4)$, organic-rich $\left(10<\mathrm{DOC}<50 \mathrm{mg} \mathrm{L}^{-1}\right)$ surface waters of western Siberia.

Concentrations of $\mathrm{Na}, \mathrm{Mn}, \mathrm{Zn}, \mathrm{As}, \mathrm{Rb}$ and $\mathrm{Sr}$ in winter aerosols are similar (within a factor of 2) to lake water concentrations during spring. Concentrations of DIC, $\mathrm{Cl}, \mathrm{SO}_{4}$, $\mathrm{Mg}, \mathrm{Ca}, \mathrm{Cr}, \mathrm{Co}, \mathrm{Ni}, \mathrm{Cu}, \mathrm{Mo}, \mathrm{Cd}, \mathrm{Sb}, \mathrm{Cs}, \mathrm{Pb}$ and $\mathrm{U}$ in filtered snow water are close to or higher than those in lakes. In the permafrost-free zone, only $\mathrm{Zn}, \mathrm{Cd}, \mathrm{W}, \mathrm{Pb}, \mathrm{Cs}$ and $\mathrm{Sb}$ fluxes in rivers during the May-June period can be provided by the dissolved fraction of the snowmelt. However, the impact of snowmelt on river export fluxes in spring strongly increases northward for $\mathrm{DIC}, \mathrm{Cl}, \mathrm{SO}_{4}, \mathrm{Na}, \mathrm{Mg}, \mathrm{Ca}, \mathrm{Cd}, \mathrm{Pb}, \mathrm{Sb}, \mathrm{Cr}, \mathrm{Cu}$, $\mathrm{Ni}, \mathrm{As}, \mathrm{Mo}, \mathrm{Rb}$ and $\mathrm{U}$. In the permafrost zone, $\geq 50 \%$ of riverine fluxes of these elements during spring floods can be provided by the snowmelt. The reason for such a high sensitivity of WSL surface reservoirs to atmospheric deposition lies in the feeding of surface waters by essentially organic (moss, peat) soil profiles.

Data availability. The full data set of major and trace element concentrations in snow water $(<0.45 \mu \mathrm{m})$ and snow particles sampled across the latitudinal profile of Western Siberia Lowland is available via ResearchGate (https://www.researchgate.net/publication/ 309666956; Pokrovsky, 2016).

\section{The Supplement related to this article is available online at https://doi.org/10.5194/hess-21-5725-2017- supplement.}

Competing interests. The authors declare that they have no conflict of interest.

Acknowledgements. This work was supported by the RF Federal Target Program, grant no. RFMEFI58717X0036. We would like to thank Alexander P. Lisitzin for valuable recommendations, and Jonathan Prunier, Manuel Henry, Frederick Candaudaup and Aurelie Lanzanova help in analytical work. We are grateful to 
associate editor Laurent Pfister for his editorial corrections. The authors acknowledge the NOAA Air Resources Laboratory (ARL) for the provision of the HYSPLIT transport model and READY website (http://www.arl.noaa.gov/ready.html).

Edited by: Laurent Pfister

Reviewed by: two anonymous referees

\section{References}

Ariés, S., Valladon, M., Polvé, M., and Dupré, B.: A routine method for oxide and hydroxide interference corrections in ICP-MS chemical analysis of environmental and geological samples, Geostandard. Newslett., 24, 19-31, https://doi.org/10.1111/j.1751-908X.2000.tb00583.x, 2000.

Baltrènaitè, E., Baltrènas, P., Lietuvninkas, A., Šerevičienė, V., and Zuokaitè, E.: Integrated evaluation of aerogenic pollution by airtransported heavy metals $(\mathrm{Pb}, \mathrm{Cd}, \mathrm{Ni}, \mathrm{Zn}, \mathrm{Mn}$ and $\mathrm{Cu})$ in the analysis of the main deposit media, Environ. Sci. Pollut. R., 21, 299-313, 2014.

Barrie, L. A.: Arctic air pollution: an overview of current knowledge, Atmos. Environ., 20, 643-663, 1986.

Barrie, L. A. and Barrie, M. J.: Chemical components of lower tropospheric aerosols in the high Arctic: Six year of observation, J. Atmos. Chem., 11, 211-226, 1990.

Baulin, V. V.: Permanently frozen rocks of oil and gas producing regions of the USSR, Nauka, Moscow, Russia, 1985 (in Russian).

Baulin, V. V., Belopukhova, E. B., Dubikov, G. I., and Shmelev, L. M.: Geocryological conditions of western Siberia Lowland, Nauka, Moscow, Russia, 1967 (in Russian).

Beilman, D. W., MacDonald, G. M., Smith, L. C., and Reimer, P. J.: Carbon accumulation in peatlands of West Siberia over the last 2000 years, Global Biogeochem. Cy., 23, GB1012, https://doi.org/10.1029/2007GB003112, 2009.

Bini, C., Sartori, G., Wahsha, M., and Fontana, S.: Background levels of trace elements and soil geochemistry at regional level in NE Italy, J. Geochem. Explor. 109, 125-133, https://doi.org/10.1016/j.gexplo.2010.07.008, 2011.

Bokhorst, S., Pedersen, S. H., Brucker, L., Anisimov, O., Bjerke, J. W., Brown, R. D., Ehrich, D., Essery, R. L. H., Heilig, A., Ingvander, S., Johansson, C., Johansson, M., Jónsdóttir, I. S., Inga, N., Luojus, K., Macelloni, G., Mariash, H., McLennan, D., Rosqvist, G. N., Sato, A., Savela, H., Schneebeli, M., Sokolov, A., Sokratov, S. A., Terzago, S., Vikhamar-Schuler, D., Williamson, S., Qiu, Y., and Callaghan, T. V.: Changing Arctic snow cover: A review of recent developments and assessment of future needs for observations, modelling, and impacts, Ambio, 45, 516-537, https://doi.org/10.1007/s13280-016-0770-0, 2016.

Botch, M. S., Kobak, K. I., Vinson, T. S., and Kolchugina, T. P.: Carbon pools and accumulation in peatlands of the former Soviet Union, Global Biogeochem. Cy., 9, 37-46, https://doi.org/10.1029/94GB03156, 1995.

Boyarkina, A. P., Baikovsky, V. V., Vasiliev, N. V., Glukhov, G. G., Medvedev, M. A., Pisareva, L. F., Rezchikov, V. I., and Shelud'ko, S. I.: Aerosols in natural tablet of Siberia, Publishing house of Tomsk State University, Tomsk, Russia, 157 pp., 1993 (in Russian).
Brown, J., Ferrians, O. J. J., Heginbottom, J. A., and Melnikov, E. S.: International Permafrost Association circum-Arctic map of permafrost and ground ice conditions, scale 1: 10000000 , U.S. Geol. Surv., Washington, D.C., USA, 1997.

Bulygina, O. N., Razuvaev, V. N., and Korshunova, N. N.: Changes in snow cover over Northern Eurasia in the last few decades, Environ. Res. Lett., 4, 045026, https://doi.org/10.1088/17489326/4/4/045026, 2009.

Callaghan, T. V., Johansson, M., Brown, R. D., Groisman, P. Ya., Labba, N., Radionov, V., Bradley, R. S., Blangy, S., Bulygina, O. N., Christensen, T. R., Colman, J. E., Essery, R. L. H., Forbes, B. C., Forchhammer, M. C., Golubev, V. N., Honrath, R. E., Juday, G. P., Meshcherskaya, A. V., Phoenix, G. K., Pomeroy, J., Rautio, A., Robinson, D. A., Schmidt, N. M., Serreze, M. C., Shevchenko, V. P., Shiklomanov, A. I., Shmakin, A. B., Skold, P., Sturm, M., Woo, M., and Wood, E. F.: Multiple effects of changes in Arctic snow cover, Ambio, 40, 32-45, 2011.

Chekushin, V. A., Bogatyrev, I. V., de Caritat, P., Niskavaara, H., and Reimann, C.: Annual atmospheric deposition of 16 elements in eight catchments of the central Barents region, Sci. Total Environ., 220, 95-114, 1998.

Chessel, D., Dufour, A. B., and Thioulouse, J.: The ade4 package I: One-table methods, R News, 4/1, 5-10, 2004.

Darby, D. A., Burckle, L. H., and Clark, D. L.: Airborne dust on the Arctic pack ice: Its composition and fallout rate, Earth Planet. Sci. Lett., 24, 166-172, 1974.

de Caritat, P., Reimann, C., Chekushin, C., Bogatyrev, I., Niskavaara, H., and Braun, J.: Mass balance between emission and deposition of airborne contaminants, Environ. Sci. Technol., 31, 2966-2972, 1997.

de Caritat, P., Äyräs, M., Niskavaara, H., Chekushin, V., Bogatyrev, I., and Reimann, C.: Snow composition in eight catchments in the central Barents Euro-Arctic region, Atmos. Environ., 32, 26092626, 1998.

de Caritat, P., Hall, G., Gislason, S., Belsey, W., Braun, M., Goloubeva, N. I., Olsen, H. K., Scheie, J. O., and Vaive, J. E.: Chemical composition of arctic snow: concentration level and regional distribution of major elements, Sci. Total Environ., 336, 183-199, 2005.

De la Cruz, O. and Holmes, S.: The duality diagram in data analysis: Examples of modern applications, Ann. Appl. Stat., 5, 22662277, https://doi.org/10.1214/10-AOAS408, 2011.

Draxler, R. R. and Rolf, G. D.: HYSPLIT (Hebrid Single-Particle Lagrangian Integrated Trajectory), Silver Spring, MD, NOAA Air Resources Lab. Mod access via NOAA ARL READY Website, available at: http://www.arl.noaa.gov/ready/hysplit4.html (last access: 15 November 2017), 2003.

Duce, R. A., Hoffman, G. L., Ray, B. J., Fletcher, I. S., Wallace, G. T., Fasching, J. L., Piotrowicz, S. R., Walsh, P. R., Hoffman, E. J., Miller, J. M., and Heffter, J. L.: Trace metals in the marine atmosphere: sources and fluxes, in: Marine Pollutant Transfer, edited by: Windom, H. L. and Duce, R. A., Lexington Books, Toronto, Canada, 77-119, 1976.

Ermolov, Yu. V., Makhatkov, I. D., and Khudyaev, S. A.: Background concentration of chemical elements in snow cover of the typical regions of the Western Siberia, Optika Atmosfery i Okeana, 27, 790-800, 2014 (in Russian).

Evangeliou, N., Shevchenko, V. P., Yttri, K. E., Eckhardt, S., Sollum, E., Pokrovsky, O. S., Kobelev, V. O., Korobov, V. B., 
Lobanov, A. A., Starodymova, D. P., Vorobiev, S. N., Thompson, R. L., and Stohl, A.: Origin of elemental carbon in snow from Western Siberia and northwestern European Russia during winter-spring 2014, 2015 and 2016, Atmos. Chem. Phys. Discuss., https://doi.org/10.5194/acp-2017-542, in review, 2017.

Evseeva, N. C., Kvasnikova, Z. N., Romashova, T. N., and Osintzeva N. V.: Aeolian erosion of soil during cold period of the year on Tom-Yaiskoe watershed divide (Western Siberia), Geogr. Nat. Resour., 3, 101-105, 2003.

Franzén, L. G., Hjelmroos, M., Kållberg, P., Brorström-Lundén, E., Juntto, S., and Savolainen, A.-L.: The "yellow snow" episode of northern Fennoscandia, march 1991 - a case study of longdistance transport of soil, pollen and stable organic compounds, Atmos. Environ., 28, 3587-3604, 1994.

Frey, K. E. and Smith, L. C.: How well do we know northern land cover? Comparison of four global vegetation and wetland products with a new ground-truth database for West Siberia, Global Biogeochem. Cy., 21, GB1016, https://doi.org/10.1029/2006GB002706, 2007.

Garbarino, J. R., Snyder-Conn, E., Leiker, T. J., and Hoffman, G. L.: Contaminants in arctic snow collected over northwest Alaskan sea ice, Water Air Soil Poll., 139, 183-214, 2002.

Gordeev, V. V. and Lisitzin, A. P.: Heavy metals in snow and ice cover of the Barents Sea, Oceanology, 45, 737-744, 2005.

Gourdol, L., Hissler, C., Hoffmann, L., and Pfister, L.: On the potential for the Partial Triadic Analysis to grasp the spatio-temporal variability of groundwater hydrochemistry, Appl. Geochem., 39, 93-107, 2013.

Guéguen, C., Cuss, C. W., and Cho, S.: Snowpack deposition of trace elements in the Athabasca oil sands region, Canada, Chemosphere, 153, 447-454, https://doi.org/10.1016/j.chemosphere.2016.03.020, 2016.

Hartigan, J.: Clustering Algorithms, John Wiley and Sons, New York, USA, 1975.

Huang, Z., Huang, J., Hayasaka, T., Shanshan Wang, S., Zhou, T., and Jin, H.: Short-cut transport path for Asian dust directly to the Arctic: a case study, Environ. Res. Lett., 10, 114018, https://doi.org/10.1088/1748-9326/10/11/114018, 2015.

Kabata-Pendias, A. and Pendias, H.: Trace Elements in Soils and Plants, CRC Press, Boca Raton, Florida, USA, 304 pp., 1984.

Kang, S., Zhang, Q., Kaspari, S., Qin, D., Cong, Z., Ren, J., and Mayewski, P. A.: Spatial and seasonal variations of elemental composition in Mt. Everest (Qomolangma) snow/firn, Atmos. Environ., 41, 7208-7218, 2007.

Karnatzevicth, I. V. and Khruschev, S. A.: A computer system of mass calculation of running water balances of river watersheds from poorly studied territories, Gos Ped Institut, Omsk, Russia, 174 pp., 2014.

Kashulina, G., de Caritat, P., and Reimann, C.: Snow and rain chemistry around the "Severonikel" industrial complex, NW Rurria: Current status and retrospective analysis, Atmos. Environ., 89, 672-682, 2014.

Kaufman, L. and Rousseeuw, P. J.: Finding Groups in Data, John Wiley and Sons Inc., New York, USA, 368 pp., 2005.

Krachler, M., Zheng, J., Koerner, R., Zdanowicz, C., Fisher, D., and Shotyk, W.: Increasing atmospheric antimony contamination in the northern hemisphere: snow and ice evidence from Devon Island, Arctic Canada, J. Environ. Monitor., 7, 1169-1176, 2005.
Laing, J. R., Hopke, P. K., Hopke, E. F., Husain, L., Durkiewcz, V. A., Paatero, J., and Viisanen, Y.: Long-term particle measurements in Finnish Arctic: Part I-Chemical composition and trace metal solubility, Atmos. Environ. 88, 275-284, 2014.

Laing, J. R., Hopke, P. K., Hopke, E. F., Husain, L., Durkiewcz, V. A., Paatero, J., and Viisanen, Y.: Positive matrix factorization of 47 years of particle measurements in Finnish Arctic, Aerosol Air Qual. Res., 15, 188-207, 2015.

Levitan, D. M., Zipper, C. E., Donovan, P., Schreiber, M. E., Seal, R. R., Engle, M., Chermak, J., Bodnar, R. J., Johnson, D. K., and Aylor, J. G.: Statistical analysis of soil geochemical data to identify pathfinders associated with mineral deposits: an example from the Coles Hill uranium deposit, Virginia, USA, J. Geochem. Explor. 154, 238-251, 2015.

Lin, X., Wang, X., Zhang, B., and Yao, W.: Multivariate analysis of regolith sediment geochemical data from the Jinwozi gold field, north-western China, J. Geochem. Explor. 137, 48-54, 2014.

Lisitzin, A. P.: Processes of Ocean Sedimentation, Lithology and Geochemistry, Nauka, Moscow, Russia, 391 pp., 1978.

Lisitzin, A. P.: Sea-ice and Iceberg Sedimentation in the Ocean: Recent and Past, Springer, Berlin, Germany, 563 pp, https://doi.org/10.1007/978-3-642-55905-1, 2002.

Lisitzin, A. P.: Arid sedimentation in the oceans and atmospheric particulate matter, Dispersed Russian Geology Geophysics, 52, 1100-1133, https://doi.org/10.1016/j.rgg.2011.09.006, 2011.

Lisitzin, A. P., Lukashin, V. N., and Dara, O. M.: Composition and fluxes of minerals in suspended particulate matter from the water column of the Caspian Sea, Dokl. Earth Sci., 463, 733-737, https://doi.org/10.1134/S1028334X15070120, 2015.

Manasypov, R. M., Pokrovsky, O. S., Kirpotin, S. N., and Shirokova, L. S.: Thermokarst lake waters across the permafrost zones of western Siberia, The Cryosphere, 8, 1177-1193, https://doi.org/10.5194/tc-8-1177-2014, 2014.

Manasypov, R. M., Vorobyev, S. N., Loiko, S. V., Kritzkov, I. V., Shirokova, L. S., Shevchenko, V. P., Kirpotin, S. N., Kulizhsky, S. P., Kolesnichenko, L. G., Zemtzov, V. A., Sinkinov, V. V., and Pokrovsky, O. S.: Seasonal dynamics of organic carbon and metals in thermokarst lakes from the discontinuous permafrost zone of western Siberia, Biogeosciences, 12, 30093028, https://doi.org/10.5194/bg-12-3009-2015, 2015.

Moragues-Quiroga, C., Juilleret, J., Gourdol, L., Pelt, E., Perrone, T., Aubert, A., Morvan, G., Chabaux, F., Legout, A., Stille, P., and Hissler, C.: Genesis and evolution of regoliths: Evidence from trace and major elements and $\mathrm{Sr}-\mathrm{Nd}-\mathrm{Pb}-\mathrm{U}$ isotopes, Catena, 149, 185-198, 2017.

Moskovchenko, D. V. and Babushkin, A. G.: Peculiarities of formation of chemical composition of snow waters (on example of Khanty-Mansi autonomous district), Earth Cryosphere, XVI, 71$81,2012$.

Mullen, R. E., Darby, D. A., and Clark, D. L.: Significance of atmospheric dust and ice rafting for Arctic sediment, Geol. Soc. Am. Bull. 83, 205-212, 1972.

Nguyen, Q. T., Skov, H., Sørensen, L. L., Jensen, B. J., Grube, A. G., Massling, A., Glasius, M., and Nøjgaard, J. K.: Source apportionment of particles at Station Nord, North East Greenland during 2008-2010 using COPREM and PMF analysis, Atmos. Chem. Phys., 13, 35-49, https://doi.org/10.5194/acp-13-352013, 2013. 
Niu, H., He, Y., Kang, S., Lu, X., Shi, X., and Wang, S.: Chemical composition of snow from Mt. Yulong, southeastern Tibetan Plateau, J. Earth Syst. Sci., 125, 403-416, 2016.

Niu, H., Kang, S., Shi, X., He, Y., Lu X., Shi, X., Paudyal, R., Du, J., Wang, S., Du, J., and Chen, J.: Water-soluble elements in snow and ice on Mt. Yulong, Sci. Total Environ., 574, 889-900, 2017.

Novikov, S. M., Moskvin, Y. P., Trofimov, S. A., Usova, L. I., Batuev, V. I., Tumanovskaya, S. M., Smirnova, V. P., Markov, M. L., Korotkevicth, A. E., and Potapova, T. M.: Hydrology of bog territories of the permafrost zone of western Siberia, BBM publ. House, St. Petersburg, Russia, 535 pp., 2009 (in Russian).

Nürnberg, D., Wollenburg, I., Dethleff, D., Eicken, H., Kassens, H., Letzig, T., Reimnitz, E., and Thiede, J.: Sediments in Arctic sea ice: Implications for entrainment, transport and release, Mar. Geol., 119, 185-214, 1994.

Pacyna, J. M. and Ottar, B.: Origin of natural constituents in the Arctic aerosols, Atmos. Environ., 23, 809-815, 1989.

Pokrovsky, O. S.: Full data set of major and trace element concentration in snow water $(0.45 \mu \mathrm{m})$ and snow parcticles sampled across the latitudinal profile of Western Siberia Lowland, Research Gate, https://doi.org/10.13140/RG.2.2.12156.54408, 2016.

Pokrovsky, O. S., Manasypov, R. M., Loiko, S., Shirokova, L. S., Krickov, I. A., Pokrovsky, B. G., Kolesnichenko, L. G., Kopysov, S. G., Zemtzov, V. A., Kulizhsky, S. P., Vorobyev, S. N., and Kirpotin, S. N.: Permafrost coverage, watershed area and season control of dissolved carbon and major elements in western Siberian rivers, Biogeosciences, 12, 63016320, https://doi.org/10.5194/bg-12-6301-2015, 2015.

Pokrovsky, O. S., Manasypov, R. M., Loiko, S. V., Krickov, I. A., Kopysov, S. G., Kolesnichenko, L. G., Vorobyev, S. N., and Kirpotin, S. N.: Trace element transport in western Siberian rivers across a permafrost gradient, Biogeosciences, 13, 1877-1900, https://doi.org/10.5194/bg-13-1877-2016, 2016a.

Pokrovsky, O. S., Manasypov, R. M., Loiko, S. V., and Shirokova, L. S.: Organic and organo-mineral colloids of discontinuous permafrost zone, Geochim. Cosmochim. Ac., 188, 1-20, 2016 b.

Polishchuk Y. M., Bogdanov, A. N., Polishchuk, V. Y., Manasypov, R. M., Shirokova, L. S., Kirpotin, S. N., and Pokrovsky, O. S.: Size distribution, surface coverage, water, carbon, and metal storage of thermokarst lakes in the permafrost zone of the Western Siberia Lowland, Water, 9, 228, https://doi.org/10.3390/w9030228, 2017.

Quinn, P. K., Bates, T. S., Baum, E., Doubleday, N., Fiore, A. M., Flanner, M., Fridlind, A., Garrett, T. J., Koch, D., Menon, S., Shindell, D., Stohl, A., and Warren, S. G.: Shortlived pollutants in the Arctic: their climate impact and possible mitigation strategies, Atmos. Chem. Phys., 8, 1723-1735, https://doi.org/10.5194/acp-8-1723-2008, 2008.

Raputa, V. F.: Experimental and modeling studies of aerosol deposition in the vicinity of gas torch burning, Vestnik NGY, Ser. Mathematics, mechanics and Informatics, 13, 96-102, 2013 (in Russian).

Rasmussen, P. E.: Long-range atmospheric transport of trace metals: the need for geoscience perspectives, Environ. Geol., 33, 96108, 1998.

Raudina, T. V., Loiko, S. V., Lim, A. G., Krickov, I. V., Shirokova, L. S., Istigechev, G. I., Kuzmina, D. M., Kulizhsky, S. P., Vorobyev, S. N., and Pokrovsky, O. S.: Dissolved organic carbon and ma- jor and trace elements in peat porewater of sporadic, discontinuous, and continuous permafrost zones of western Siberia, Biogeosciences, 14, 3561-3584, https://doi.org/10.5194/bg-143561-2017, 2017.

Reimann, C. and de Caritat, P.: Intrinsic flaws of element enrichment factors (EFs) in environmental geochemistry, Environ. Sci. Technol. 34, 5084-5091, 2000.

Reimann, C., Halleraker, J. H., Kashulina, G., and Bogatyrev, I.: Comparison of plant and precipitation chemistry in catchments with different levels of pollution on the Kola Peninsula, Russia, Sci. Total Environ., 243/244, 169-191, 1991.

Reimann, C., Niskavaara, H., de Caritat, P., Finne T. E., Äyräs, M., and Chekushin, V.: Regional variation of snowpack chemistry in the vicinity of Nikel and Zapoljarnij, Russia, northern Finland and Norway, Sci. Total Environ., 182, 147-158, 1996.

Reimann, C., Banks, D., and de Caritat, P.: Impacts of airborne contamination on regional soil and water quality: The Kola Peninsula, Russia, Environ. Sci. Technol., 34, 2727-2732, 2000.

Reimann, C., Filzmoser, P., Garrett, R. G., and Dutter, R.: Statistical Data Analysis Explained: Applied Environmental Statistics with R, John Wiley and Sons Ltd., New York, USA, 343 pp., 2008.

Reinosdotter, K. and Viklander, M.: A comparison of snow quality in two Swedish municipalties - Luleå and Sundsvall, Water Air Soil Poll., 167, 3-16, 2005.

Resources of Surface Waters of USSR: Altai and Western Siberia, in: Middle Ob, edited by: Panina, N. A., Vol. 15, Issue 2, Gidrometeoizdat, Leningrad, Russia, 408 pp., 1972.

Resources of Surface Waters of USSR: Altai and Western Siberia, in: Low Irtush and Low Ob, edited by: Vodogrtesky, V. E., Vol. 15, Issue 3, Gidrometeoizdat, Leningrad, Russia, 424 pp., 1973.

Ross, H. B. and Granat, L.: Deposition of atmospheric trace metals in northern Sweden as measured in the snowpack, Tellus, 38B, 27-43, 1986.

Rossini Oliva, S. and Fernández Espinosa, A. J.: Monitoring of heavy metals in topsoils, atmospheric particles and plant leaves to identify possible contamination sources, Microchem. J., 86, 131-139, 2007.

Rudnick, R. L. and Gao, S.: Composition of the continental crust, in: Treatise on Geochemistry, edited by: Holland, H. D. and Turekian, K. K., Elsevier V, Amsterdam, the Netherlands, 3, 163, 2003.

Santelman, M. V. and Gorham, E.: The influence of airborne road dust on the chemistry of Sphagnum mosses, J. Ecol., 76, 12191231, 1988.

Schot, P. P. and van der Wal, J.: Human impact on regional groundwater composition through intervention in natural flow patterns and changes in land use, J. Hydrol., 134, 297-313, 1992.

Shevchenko, V.: The influence of aerosols on the oceanic sedimentation and environmental conditions in the Arctic, Berichte zur Polar- und Meeresforschung, Alfred Wegener Institute, Bremerhaven, Germany, 464, 149 pp., 2003.

Shevchenko, V. P., Lisitzin, A. P., Vinogradova, A. A., Smirnov, V. V., Serova, V. V., and Stein, R.: Arctic aerosols. Results of tenyear investigations, Atmos. Ocean. Optics, 13, 510-533, 2000.

Shevchenko, V. P., Lisitsyn, A. P., Polyakova, E. I., Dethleff, D., Serova, V. V., and Stein, R.: Distribution and composition of sedimentary material in the snow cover of arctic drift ice (Fram Strait), Dokl. Earth Sci., 383A, 278-281, 2002. 
Shevchenko, V. P., Lisitzin A., Vinogradova, A., and Stein R.: Heavy metals in aerosols over the seas of the Russian Arctic, Sci. Total Environ., 306, 11-25, https://doi.org/10.1016/S00489697(02)00481-3, 2003.

Shevchenko, V. P., Korobov, V. B., Lisitzin, A. P., Aleshinskaya, A. S., Bogdanova, O. Yu., Goryunova, N. V., Grishchenko, I. V., Dara, O. M., Zavernina, N. N., Kurteeva, E. I., Novichkova, E. A., Pokrovsky, O. S., and Sapozhnikov, F. V.: First data on the composition of atmospheric dust responsible for yellow snow in northern European Russia in March 2008, Dokl. Earth Sci., 431, 497-501, https://doi.org/10.1134/S1028334X10040185, 2010.

Shevchenko, V. P., Vorob'ev, S. N., Kirpotin, S. N., Kritskov, I. V., Manasypov, R. M., Pokrovsky, O. S., and Politova, N. V.: Investigations of insoluble particles in the snow cover of Western Siberia from Tomsk to the Ob estuary, Optika Atmosfery i Okeana, 28, 499-504, https://doi.org/10.15372/AOO20150601, 2015 (in Russian).

Shevchenko, V. P., Vinogradova, A. A., Lisitzin, A. P., Novigatsky, A. N., Panchenko, M. V., and Pol'kin, V. V.: Aeolian and ice transport of matter (including pollutants) in the Arctic, in: Implications and Consequences of Anthropogenic Pollution in Polar environments, From Pole to Pole, edited by: Kallenborn, R., Springer-Verlag, Berlin Heidelberg, Germany, 59-73, https://doi.org/10.1007/978-3-642-12315-3_5, 2016.

Shotyk, W., Nesbitt, H. W., and Fyfe, W. S.: The behaviour of major and trace elements in complete vertical peat profiles from three Sphagnum bogs, Int. J. Coal Geol., 15, 163-190, 1990.

Shotyk, W., Nesbitt, H. W., and Fyfe, W. S.: Natural and anthropogenic enrichments of trace metals in peat profiles, Int. J. Coal Geol., 20, 49-84, 1992.

Singh, V. P., Singh, P., and Haritashya, U. K.: Encyclopedia of Earth Sciences Series: Encyclopedia of Snow, Ice and Glaciers, Springer, 1253 pp., https://doi.org/10.1007/978-90-481-2642-2, 2011

Siudek, P., Frankowski, M., and Siepak, J.: Trace element distribution in the snow cover from an urban area in central Poland, Environ. Monit. Assess., 187, 225, https://doi.org/10.1007/s10661015-4446-1, 2015.

Smith, L. C., Macdonald, G. M., Velichko, A. A., Beilman, D. W., Borisova, O. K., Frey, K. E., Kremenetsky, K. V., and Sheng, Y.: Siberian peatlands as a net carbon sink and global methane source since the early Holocene, Science, 303, 353-356, 2004.

Snyder-Conn, E., Garbarino, J. R., Hoffman, G. L., and Oelkers, A.: Soluble trace elements and total mercury in Arctic Alaskan snow, Arctic, 50, 201-215, 1997.

Steinnes, E. and Friedland, A. J.: Metal contamination of natural surface soils from long-range atmospheric transport: Existing and missing knowledge, Environ. Rev., 14, 169-186, 2006.

Stepanova, V. M., Pokrovsky, O. S., Viers, J., MironychevaTokareva, N. P. Kosykh, N. P., and Vishnyakova, E. K.: Major and trace elements in peat profiles in Western Siberia: impact of the landscape context, latitude and permafrost coverage, Appl. Geochem., 53, 53-70, 2015.

Stohl, A., Klimont, Z., Eckhardt, S., Kupiainen, K., Shevchenko, V. P., Kopeikin, V. M., and Novigatsky, A. N.: Black carbon in the Arctic: the underestimated role of gas flaring and residential combustion emissions, Atmos. Chem. Phys., 13, 8833-8855, https://doi.org/10.5194/acp-13-8833-2013, 2013.
Sutherland, R. A., Tolosa, C. A., Tack, F. M., and Verloo, M. G.: Characterization of selected element concentration and enrichment ratios in background and anthropogenically impacted roadside areas, Arch. Environ. Con. Tox., 38, 428-438, 2000.

Talovskaya, A. V., Simonenkov, D. V., Filimonenko, E. A., Belan, B. D., Yazikov, E. G., Rychkova, D. A., and Il'enok, S. S.: Study of aerosol composition in Tomsk region background and urban stations (the winter period 2012/13), Optika Atmosfery i Okeana, 27, 999-1005, 2014.

Telmer, K., Bonham-Karter, G. F., Kliza, D. A., and Hall, G. E. M.: The atmospheric transport and deposition of smelter emissions: Evidence from the multi-element geochemistry of snow, Quebec, Canada, Geochim. Cosmochim. Ac., 68, 2961-2980, 2004.

Thioulouse, J., Chessel, D., Doledec, S., and Olivier, J. M.: ADE4: a multivariate analysis and graphical display software, Stat. Comput., 7, 75-83, https://doi.org/10.1023/A:1018513530268, 1997.

Tranter, M., Brimblecombe, P., Davies, T. D., Vincent, C. E., Abrahams, P. W., and Blackwood I.: The chemical composition of snowpack, snowfall and meltwater in the Scottish Highlands evidence for preferential elution, Atmos. Environ., 20, 517-525, 1986.

Tranter, M., Davies, T. D., Abrahams, P. W., Blackwood, I., Brimblecombe, P., and Vincent, C. E.: Spatial variability in the chemical composition of snowcover in a small, remote Scottish catchment, Atmos. Environ., 21, 853-862, 1987.

Tyrtikov, A. P.: Thawing of soils in tundra of western Siberia, in: Natural environment of western Siberia, edited by: Popov, A. I., Izd-vo MGU, Moscow, Russia, 1973 (in Russian).

Tyrtikov, A. P.: Dynamics of vegetation coverage and permafrost development in western Siberia, Nauka, Moscow, Russia, 1979 (in Russian).

Van de Velde, K., Ferrari, C., Barbante, C., Moret, I., Bellomi, T., Hong, S., and Boutron, C.: A 200 year record of atmospheric cobalt, chromium, molybdenum, and antimony in high altitude alpine firn and ice, Environ. Sci. Technol., 33, 3495-3501, 1999.

Vasil'chuk, Yu. K., Shevchenko, V. P., Lisitzin, A. P., Budantseva, N. A., Vorobiov, S. N., Kirpotin, S. N., Krizkov, I. V., Manasypov, R. M., Pokrovsky, O. S., and Chizhova, Ju. N.: Oxygen isotope and deuterium composition of snow cover on the profile of West Siberia from Tomsk to the Ob Bay, Dokl. Earth Sci., 471, 1284-1287, https://doi.org/10.1134/S1028334X1612014X, 2016.

Vasil'evskaya, V. D., Ivanov, V. V., and Bogatyrev, L. G.: Soils of North of western Siberia, Moscow University Publ. House, Moscow, Russia, 228 pp., 1986 (in Russian).

Vinogradova, A. A., Malkov, I. P., Polissar, A. V., and Khramov, N. N.: Elemental composition of the surface atmospheric aerosol in the Arctic regions of Russia, Izv. Atmos. Ocean. Phys.+, 29, 149-157, 1993.

Walker, T. R., Young, S. D., Crittenden, P. D., and Zhang, H.: Anthropogenic metal enrichment of snow and soil in north-eastern European Russia, Environ. Pollut., 121, 11-21, 2003.

Ward Jr., J. H.: Hierarchical grouping to optimize an objective function, J. Am. Stat. Assoc., 58, 236-244, 1963.

Weinbruch, S., Wiesemann, D., Ebert, M., Schütze, K., Kallenborn, R., and Ström, J.: Chemical composition and sources of aerosol particles at Zeppelin Mountain (Ny Ålesund, Svalbard): An electron microscopy study, Atmos. Environ., 49, 142-150, 2012. 
Welch, H. E., Muir, D. C. G., Billeck, B. N., Lockhart, W. L., Brunskill, G. J., Kling, H. J., Olson, M. P., and Lemoine, R. M.: Brown snow: a long-range transport event in the Canadian Arctic, Environ. Sci. Technol., 25, 280-286, 1991.

Yashchenko, I. G., Svarovskaya, L. I., and Alexeeva, M. N.: Assessment of environmental risk associated with gas flaring in Western Siberia, Optika Atmosfery i Okeana, 27, 560-564, 2014 (in Russian).

Yazikov, E. G., Talovskaya, A. V., and Gornyak, L. V.: Estimation of ecology - geochemical condition of Tomsk city territory on data of aeolian dust and soils study, Publishing house of Tomsk Polytechnical University, Tomsk, Russia, 264 pp., 2000 (in Russian).

Zakharova, E. A., Kouraev, A. V., Biancamaria, S., Kolmakova, M. V., Mognard, N. M., Zemtsov, V. A., Kirpotin, S. N., and Decharme, B.: Snow cover and spring flood flow in the northern part of Western Siberia (the Poluy, Nadym, Pur, and Taz Rivers, J. Hydrometeorol., 12, 1498-1511, 2011.
Zdanowicz, C. M., Zielinski, G. A., and Wake, C. P.: Characteristics of modern atmospheric dust deposition in snow on the Penny Ice Cap, Baffin Island, Arctic Canada, Tellus, 50B, 506-520, 1998.

Zdanowicz, C. M., Hall, G., Vaive, J., Amelin, Y., Percival, J., Girard, I., Biscaye, P., and Bory, A.: Asian dustfall in the St. Elias Monttains, Yukon, Canada, Geochim. Cosmochim. Ac., 70, 3493-3507, 2006.

Zhang, Y., Mahowald, N., Scanza, R. A., Journet, E., Desboeufs, K., Albani, S., Kok, J. F., Zhuang, G., Chen, Y., Cohen, D. D., Paytan, A., Patey, M. D., Achterberg, E. P., Engelbrecht, J. P., and Fomba, K. W.: Modeling the global emission, transport and deposition of trace elements associated with mineral dust, Biogeosciences, 12, 5771-5792, https://doi.org/10.5194/bg-125771-2015, 2015. 